\title{
The U-shape of happiness in Scotland
}

\author{
David N. F. Bell ${ }^{1}$ | David G. Blanchflower ${ }^{2,3,4}$
}

\author{
${ }^{1}$ Division of Economics, Management \\ School, University of Stirling, IZA and CPC, \\ Stirling, UK \\ ${ }^{2}$ Bruce V. Rauner Professor of Economics, \\ Dartmouth College, Hanover, NH, USA \\ ${ }^{3}$ Adam Smith Business School, University of \\ Glasgow, Glasgow, UK \\ ${ }^{4}$ NBER, Cambridge, NH, USA

\section{Correspondence} \\ David Blanchflower, Bruce V. Rauner \\ Professor of Economics, Department of \\ Economics, Dartmouth College, Hanover \\ NH 03755; Adam Smith Business School, \\ University of Glasgow, Glasgow, UK; and \\ NBER, Cambridge, MA. \\ Email: Blanchflower@dartmouth.edu
}

\begin{abstract}
We examine well-being in Scotland using micro data from the Scottish Health Survey and the UK Annual Population Surveys. We find evidence of a midlife nadir or zenith in Scotland in well-being at around age 50 using a variety of measures of both happiness and unhappiness. We confirm that higher consumption of fruit and vegetables is associated with higher levels of happiness in Scotland. We compare this with evidence for England from the Health Survey of England. The decline in well-being between youth and midlife is comparable in size to the loss of a spouse or of a job and around half of the fall in well-being in the COVID-19 lockdown. We also find a midlife peak in suicides in Scotland. Despite higher mortality and suicide rates in Scotland than in England, paradoxically we find that the Scots are happier than the English. Northern Ireland is the happiest of the four home countries. We also find evidence of $U$-shapes in England, Wales and Northern Ireland in the mid to late forties.
\end{abstract}

\section{KEYWORDS}

happiness, U-shape, well-being

\section{1 | INTRODUCTION}

This paper looks at well-being in Scotland and builds on our earlier paper on Scotland (Bell \& Blanchflower, 2007). We use micro data from the Scottish Health Survey and the UK Annual Population Survey. We compare with equivalent evidence from England. We find evidence of a midlife nadir or zenith in Scotland in well-being at around

This is an open access article under the terms of the Creative Commons Attribution License, which permits use, distribution and reproduction in any medium, provided the original work is properly cited.

(C)2021 The Authors. Scottish Journal of Political Economy published by John Wiley \& Sons Ltd on behalf of Scottish Economic Society. 
age 50 using a variety of measures of both happiness and unhappiness. The decline in well-being between youth and midlife is comparable in size to the loss of a spouse or of a job and around half of the fall in well-being during the COVID-19 lockdown. We also find a midlife peak in suicides in Scotland.

We find that those living in Scotland are happier than those living in England but paradoxically the Scots have higher mortality and suicide rates. Evidence of $U$-shapes in happiness and hump or hill shapes in unhappiness in Scotland is consistent with evidence from around the world and inconsistent with, claims made by a number of psychologists who suggest there is no such relationship. It holds for the UK whether socio-economic controls are included or not. There is a happiness curve in Scotland.

\section{2 | LITERATURE ON A U-SHAPE IN AGE IN WELL-BEING}

Several economic studies have recently found evidence of a significant and empirically large downturn in human well-being during the midlife years-so-called "happiness curves" (Rauch, 2018). Early work was based on life satisfaction and happiness data (Blanchflower \& Oswald, 2008); the research now extends to trends in unhappiness, stress, lack of sleep, depression, and even suicide (Daly et al., 2011) and across multiple data sets (Blanchflower, 2020a, 2020c). Blanchflower and Oswald (2020) show a dramatic rise in extreme misery among prime age less educated whites in the United States. There is within-person evidence of a U-shape from longitudinal surveys which focuses on changes in life satisfaction as a linear function of individual age (Cheng et al., 2017). Controlling for cohort effects has little or no impact on the U-shape (Clark, 2019 and Blanchflower, $2020 \mathrm{~b})$. There is a hill-shape in anti-depressant use which maximizes in the mid-40s in European countries (Blanchflower \& Oswald, 2016). There are U-shapes in sleep duration (Blanchflower \& Bryson, 2020). The U-shape pattern in midlife even extends beyond humans to apes (Weiss et al., 2012).

Most recently, the increases in the U.S. deaths of despair due to drugs, alcohol, and suicide occur precisely in the middle-aged, 35-64 years (Case \& Deaton, 2015, 2020). The trends in these deaths have a robust association with the same ill-being markers-unhappiness and stress-that increase in midlife and are responsible for driving up the overall mortality rate (Graham \& Pinto, 2019). A recent analysis by the OECD in How's Life? 2020, Measuring Well-Being, OECD, 2020, p. 106, shows that deaths of despair, by suicide, alcohol abuse, or drug overdoses are higher in 10 OECD countries-Slovenia; Lithuania; Latvia; Korea; Denmark; Belgium; Hungary; Austria; Finland; and Poland-than they are in the United States.

Blanchflower and Oswald (2008), showed that a U-shape in age existed in well-being data across a number of countries. Using data on 500,000 randomly sampled Americans and West Europeans, the paper found that holding other factors constant, a typical individual's happiness reaches its minimum on both sides of the Atlantic for both males and females in middle age. The minimum in age was broadly similar between advanced, East European and developing nations. The function minimized on average in midlife. For example, in Europe for both men and women it minimized at around 47 with controls including education, marital, and labour force status. For developing countries from the WVS, sweeps 1-4, minima were 43 for men and 44 for women. A maximum in age in unhappiness data for Europe was found at around age 47. Some apparent exceptions, particularly in 20 developing nations along with a few Western countries, mostly where there are small numbers of observations, to the U-shape were noted.

Subsequently, Glenn (2009) argued that it was inappropriate to include controls and what mattered was the raw data; Blanchflower and Oswald (2009) disagreed. Glenn claimed that: "the appearance of this U-shaped curve of well-being is the result of the use of inappropriate and questionable control variables" and especially marital status. It is worth rehearsing the arguments we used there again. In many countries around the world, and especially in Europe, as I illustrate in detail below, the U-shape can be found without any control variables, and a major problem with Glenn's analysis was that he focused too heavily on the United States.

Second, Blanchflower and Oswald (2009) disagreed with Glenn's methodological position, which seems to be that social scientists should not hold constant other factors when they study the relationship between well-being 
and age. Ultimately in social science, the control variables that are included in multiple regression equations we noted, must be chosen with an eye on the intellectual or policy question being answered. The summary of our argument went as follows. If the aim is to describe the data, it is reasonable to leave out most or all control variables. "Smokers die at rate $Z$ " is an acceptable statement to make. But that is not the same as "smoking changes your risk by Z," which requires other confounding variables to be controlled for such as diet, education, income, and exercise. Blanchflower and Oswald (2009) argued "it would likely be an error to use an equation without controls to tell the public what impact ageing has on happiness without separating out the effects of other variables such as, say, education, marriage or unemployment. If the aim is to understand relationships", and continued, "it will rarely be desirable to stop at bivariate patterns." We do not.

Blanchflower and Oswald (2019) examined the issue of differences between the well-being and age relationship with and without controls using seven pooled cross-country data sets, covering 51 countries and 1.3 million randomly sampled people, the paper examines the cross-sectional pattern of psychological well-being from approximately age 20 to age 90 . The data sets were (a) LFS survey for the UK, 2011-2015; (b) BRFSS for the USA, 2010 (c) Eurobarometer, 2016; (d) European Social Survey 2002-2014; (e) ISSP 2012; (f) GSS for the USA, 19722014; (g) Latino Barometer 2013 and 2015.

The paper described the two conceptual approaches. One studied raw numbers on well-being and age which we termed the descriptive approach. The second studied the patterns in regression equations for well-being (i.e. adjusting for other influences). This was termed the ceteris-paribus analytical approach. The paper applied each and compared the patterns of life satisfaction and happiness. Using the first method, evidence of a midlife low was found in five of the seven data sets; the two that did not were both for the United States. Using the second method, all seven data sets produced evidence consistent with a midlife low in well-being. In this paper, we report estimates with and without controls, which turn out to generate very similar results in Scotland as either way a midlife low in well-being is estimated in the mid-40s.

The evidence that well-being reaches a low point in midlife in most countries in the world is now well documented in the literature. It makes no difference what data file is used or which question is asked, and whether it relates to unhappiness or happiness. In recent work, Blanchflower (2020a) has examined the relationship between well-being and age and found it in 145 countries using controls for education, gender, marital, and labour force status on many millions of people.

U-shapes were found in 109 developing countries and 36 developed countries including the UK and every member country of the European Union and the OECD. A recent study found a U-shape in age for Pakistan, which was not on that list, which now means the happiness U-shape in age has been found in 146 countries (Shams \& Kadow, 2018). Here, we add another four taking the total to 149 countries-deducting the UK-with the four home nations of Scotland, England, Wales, and Northern Ireland.

No evidence was found that cohort effects have any impact on the findings of a U-shape. Data were used from 14 different survey series to estimate 477 separate country level estimates that minimize, on average, after 48.3 years. There were 241 estimates from developed countries with an average minimum of 46.7 and 236 estimates from developing countries with a mean of 49.9 years. It made little difference which question was used, how the responses were coded or when the question was asked. Blanchflower and Graham $(2020,2021)$ also present widespread evidence of $U$-shapes across countries.

There have also been claims that the $\mathrm{U}$-shape found in the Eurobarometer data is actually an M-shape rather than a U-shape, with an early jump in well-being in age before a midlife drop. This arises in the data because of the omission of young happy students (Blanchflower, 2020b). When the young happy students are included, there is a well-defined U-shape even in the raw data as well as with socio-economic controls.

Analogously, Blanchflower (2020c) found a hump shape in age using 20 different unhappiness questions among 14 million people in 168 countries. He used 20 different individual characterizations of unhappiness including many not good mental health days; anxiety; worry; loneliness; sadness; stress; pain; strain, depression and bad nerves; phobias and panic; being downhearted; having restless sleep; losing confidence in oneself; not being able to overcome 
difficulties; being under strain; being unhappy; feeling a failure; feeling left out; feeling tense; and thinking of yourself as a worthless person. Once again, the nadir of well-being in midlife occurred at the end of the forties. In most instances, the zenith of well-being was also found without controls. There is a hump or hill shaped unhappiness curve in age.

Graham and Pozuelo (2017) analysed the happiness curve within 46 individual countries, including controls for gender, education, marital, and employment status and household income and found U-shapes. They also looked at how the happiness curve varied depending on where in the well-being distribution individuals were. They also extended the analysis to stress with the same controls and showed an inverted $U$. The U-shaped relationship between age and happiness was measured using data from the Gallup World Poll from 2005 to 2014 with the dependent variable, the so-called Cantril ladder, based on an individual's reports on the where they would put themselves on an eleven-point ladder in which their lives compare to the best possible life they can imagine, held in 44 of the 46 countries, and a reverse $U$ held for stress in almost as many. Fortin et al. (2015) using the same Gallup World Poll data also find evidence of an inverse $U$-shape in age for stress and also find the same for worry and anger in the raw data, without controls.

A new study by de Pedraza et al. (2020) looked at life dissatisfaction and anxiety from a survey collected from 2,565 respondents from 23 March to 30 April 2020 in 25 advanced and developing countries. The data were from the continuous, voluntary coronavirus web-survey conducted by Wage Indicator Foundation in collaboration with the University of Amsterdam and the European Commission. They found hill shapes in age. "The U-shaped relationship between ageing and subjective well-being is well documented in the literature and holds worldwide with individual satisfaction scores (ceteris paribus) reaching a minimum level between 40 and 60 ... Our outcomes confirm this result... The maximum dissatisfaction and anxiety levels are attained at age 38 and 33 respectively." When they estimated models only controlling for gender, education, marital and labour force status, and countryfixed effects as in Blanchflower (2020b), the maximum dissatisfaction level they found was attained at age 40.

A few prominent papers in psychology dismiss the midlife downturn as an illusion. Myers (2000, p. 58), for example, argued that "although many people believe there are unhappy times of life- times of adolescent stress, midlife crisis, or old age decline - repeated surveys across the industrialized world reveal that no time in life is notably happiest and most satisfying". In contrast, Argyle concluded that studies of life satisfaction found that it increased with age (Argyle, 1999, 2001). A survey by Diener et al. (1999, p. 291) concluded that "recent studies converge to show that life satisfaction often increases, or at least does not drop, with age".

Jebb et al. (2020) and Galambos et al. (2020) have also recently claimed that there is no U-shape in happiness. For example, Jebb and co-authors claim, without foundation, that "a fair bit of longitudinal and cross-sectional research has shown that levels of happiness remain relatively stable across the life span" and that "much about the U shape has been overblown." Blanchflower and Graham (2020, 2021) re-estimated a happiness equation with an updated version of the same Gallup World Poll data and found U-shapes in 155 countries. Diener et al. (2018) concurred that "an age-life satisfaction association is typically a U-shape; people in their 20s as well as in their 70 s and 80 s are more satisfied with their lives in general than those in their late 40s and early 50s."

As another example, Galambos et al. (2020) claimed that "the conclusion that happiness declines from late adolescence to midlife (the first half of the $U$ shape) is premature, and possibly wrong." The empirical literature they summarize from an internet search, based on 29 papers that were published in English in peer reviewed papers between 2013 and 2019, (b) tested for age differences (cross-sectional) or changes with age (longitudinal) in global measures of life satisfaction or happiness; and (c) spanned the teens or 20s into the 60s (cross-sectional studies) or had at least two times of measurement and spanned the periods of young adulthood to midlife, midlife to late life, or young adulthood to midlife to late life (longitudinal studies) they claimed were inconsistent with a U-shape.

Blanchflower and Graham (2021) disagreed noting that once Galambos and co-authors' errors and omissions are corrected almost all of the papers show U-shapes. They found that there are 111 other papers missed by Galambos et al. (2020) that also find U-shapes, including 83 in peer reviewed journals in English during the time period in question, and another 20 passing these criteria published in 2020 or forthcoming in 2021 plus a further eight in working 
papers and book chapters that all find U-shapes. ${ }^{1}$ Blanchflower and Graham (2021) presented evidence that is consistent with U-shapes using data from around the world and concluded that "happiness and life satisfaction both reach a minimum, while unhappiness maximizes in the mid-forties. This nadir in well-being is one of the most remarkable empirical patterns in social science." That seems right. We show below there is also a non-trivial U-shape in well-being in Scotland and the other three home countries, also with minima in the mid to late forties.

\section{3 | EMPIRICAL EVIDENCE FOR SCOTLAND AND ENGLAND}

There is strong evidence for the UK in general and for Scotland in particular of a significant and statistically large U-shape. A good starting point for looking at whether there are U-shapes in age in well-being in the UK is the official data published by the Office of National Statistics (ONS). This evidence is based on four questions included in the Labour Force Surveys since 2011. We have access to the micro data from these surveys for 2016-2019. We examine these below for Scotland. The ONS have shown in relation to all four files we use that there is a nadir in well-being in midlife. The four questions Q1-Q4 are as follows.

Q1. Overall, how satisfied are you with your life nowadays? where nought is "not at all satisfied" and 10 is "completely satisfied"

Q2. How happy did you feel yesterday? (where nought is "not at all happy" and 10 is "completely happy")

Q3. Overall, to what extent do you feel that the things you do in your life are worthwhile? where nought is "not at all worthwhile" and 10 is "completely worthwhile"

Q4. How anxious did you feel yesterday? (where nought is "not at all anxious" and 10 is "completely anxious")

The ONS have published official, nationally representative, data on the variation in these four well-being measures which have grown over time. Table 1 sets out how these well-being data vary by region and age. Scotland is the least happy region with only London lower ranked in terms of life satisfaction and happiness which is consistent with what we found in Bell and Blanchflower (2007). The West Midlands ranks lower on worthwhile. Northern Ireland is especially happy. Scotland is ranked in the middle of the pack in terms of anxiety.

Of note is that there is an obvious $U$-shape in age in the first three columns with the minima in the age range 45-54. Anxiety has a maximum in two categories 30-34 and 40-44. It is worth quoting the ONS in full on their findings on well-being $\mathrm{U}$-shapes. ${ }^{2}$ This is not consistent with claims made by psychologists that no $\mathrm{U}$-shapes exist.

Considering first the measure of life satisfaction, evidence of a U-shaped curve holds true, but only for those aged 75 and under. For those aged between 16 to 19, the youngest age group presented in this analysis, average ratings of life satisfaction were high. However, after levelling off between the ages of 20 to 34, ratings become progressively lower through middle years, reaching their lowest point among those aged between 45 to 54 . Average ratings then begin to increase and peak again for those aged between 65 to 79, returning to a high level similar to that observed in the youngest age group. Average ratings of life satisfaction then begin to decline through the oldest age groups.

Again, considering only those under the age of 75 , a broadly similar $U$-shaped curve can be observed for ratings of happiness. However, the distribution is less symmetrical because average

\footnotetext{
${ }^{1}$ https://sites.dartmouth.edu/blanchflower/files/2020/10/Appendix-for-Blanchflower-Graham-Perspectives-paper.pdf

${ }^{2}$ 'Measuring National Well-being: At what age is Personal Well-being the highest?', 2 February 2016. https://www.ons.gov.uk/peoplepopulatio nandcommunity/wellbeing/articles/measuringnationalwellbeing/atwhatageispersonalwellbeingthehighest
} 
TABLE 1 Four well-being measures by Region and Age, UK April 2018-March 2019

\begin{tabular}{|c|c|c|c|c|}
\hline & Life satisfaction & Happiness & Worthwhile & Anxiety \\
\hline England & 30.6 & 35.4 & 36.0 & 40.8 \\
\hline North East & 32.0 & 36.6 & 38.5 & 42.8 \\
\hline North West & 30.9 & 35.3 & 36.2 & 43.5 \\
\hline Yorkshire and Humber & 31.9 & 35.6 & 37.6 & 41.0 \\
\hline East Midlands & 32.2 & 36.7 & 38.2 & 42.3 \\
\hline West Midlands & 30.5 & 34.7 & 34.1 & 42.9 \\
\hline East & 30.7 & 36.4 & 36.0 & 42.8 \\
\hline London & 26.5 & 32.4 & 32.5 & 35.6 \\
\hline South East & 31.7 & 36.5 & 36.9 & 40.0 \\
\hline South West & 31.3 & 36.0 & 37.0 & 39.9 \\
\hline Wales & 31.0 & 35.7 & 36.1 & 41.1 \\
\hline Scotland & 30.3 & 35.2 & 35.1 & 41.6 \\
\hline Northern Ireland & 37.1 & 37.7 & 41.5 & 41.1 \\
\hline $16-19$ & 36.0 & 39.0 & 34.8 & 41.2 \\
\hline $20-24$ & 27.6 & 32.3 & 31.2 & 36.2 \\
\hline $25-29$ & 29.3 & 32.3 & 32.8 & 38.6 \\
\hline $30-34$ & 29.5 & 33.7 & 35.4 & 38.0 \\
\hline $35-39$ & 27.5 & 32.1 & 34.6 & 39.0 \\
\hline $40-44$ & 25.8 & 31.3 & 33.0 & 38.0 \\
\hline $45-49$ & 25.2 & 31.4 & 33.5 & 38.3 \\
\hline $50-54$ & 25.5 & 31.2 & 32.2 & 38.9 \\
\hline $55-59$ & 28.9 & 33.5 & 35.1 & 40.6 \\
\hline $60-64$ & 32.3 & 37.4 & 38.9 & 42.2 \\
\hline $65-69$ & 40.0 & 45.0 & 44.5 & 47.7 \\
\hline $70-74$ & 40.3 & 45.1 & 45.2 & 47.9 \\
\hline $75-79$ & 38.9 & 44.1 & 43.5 & 48.2 \\
\hline $80-84$ & 40.2 & 43.3 & 41.5 & 49.3 \\
\hline $85-89$ & 38.3 & 40.3 & 37.6 & 48.9 \\
\hline 90 and over & 30.9 & 34.0 & 32.4 & 44.4 \\
\hline
\end{tabular}

The numbers in bold indicate the relevant age maxima.

https://www.ons.gov.uk/peoplepopulationandcommunity/wellbeing/datasets/measuringnationalwellbeingdomainsan dmeasures.

Source: ONS, 2019.

ratings of happiness amongst the 16 to 19 age group are lower than the average ratings for those aged between 65 to 74 .

Average worthwhile ratings demonstrate a shallow $\mathrm{U}$-shaped curve, with a small peak among those aged between 30 to 34 and a larger peak among those aged between 65 to 74

Average ratings of anxiety increased progressively through early and middle years, peaking for the 45 to 59 age groups, but then subsequently falling and remaining relatively unchanged. The fall 
TABLE 2 Suicide rates/100,000 by age in Scotland

\begin{tabular}{|c|c|c|c|c|c|c|c|c|}
\hline Age & $15-24$ & $25-34$ & $35-44$ & $45-54$ & $55-64$ & $65-74$ & $75-84$ & $\begin{array}{l}\text { All } \\
\text { ages }\end{array}$ \\
\hline 1982 & 9.1 & 16.7 & 19.3 & 25.3 & 24.5 & 18.0 & 19.5 & 14.2 \\
\hline 1983 & 7.4 & 15.6 & 18.9 & 22.3 & 21.6 & 18.5 & 14.1 & 13.0 \\
\hline 1984 & 8.8 & 16.4 & 18.6 & 18.6 & 23.8 & 18.3 & 17.1 & 13.4 \\
\hline 1985 & 10.2 & 16.3 & 20.0 & 26.5 & 22.1 & 18.7 & 18.0 & 14.7 \\
\hline 1986 & 11.9 & 17.2 & 20.3 & 20.8 & 23.1 & 21.6 & 18.3 & 15.0 \\
\hline 1987 & 13.2 & 17.2 & 20.2 & 17.1 & 20.8 & 14.4 & 16.9 & 13.9 \\
\hline 1988 & 15.6 & 19.5 & 20.5 & 21.4 & 18.7 & 17.2 & 20.2 & 15.2 \\
\hline 1989 & 12.6 & 18.4 & 19.5 & 20.5 & 20.3 & 14.2 & 15.0 & 14.1 \\
\hline 1990 & 13.5 & 23.7 & 16.6 & 21.5 & 16.3 & 19.9 & 13.4 & 14.7 \\
\hline 1991 & 13.0 & 21.4 & 18.8 & 19.8 & 15.1 & 14.7 & 12.4 & 13.9 \\
\hline 1992 & 17.1 & 24.9 & 22.8 & 20.1 & 16.4 & 11.4 & 18.4 & 15.6 \\
\hline 1993 & 19.0 & 27.7 & 26.3 & 22.8 & 18.7 & 16.8 & 13.6 & 17.9 \\
\hline 1994 & 17.8 & 23.8 & 24.9 & 21.7 & 17.0 & 13.6 & 15.6 & 16.3 \\
\hline 1995 & 15.9 & 24.2 & 23.4 & 23.4 & 17.2 & 14.6 & 16.3 & 16.4 \\
\hline 1996 & 17.7 & 25.9 & 20.5 & 22.6 & 14.3 & 18.1 & 16.4 & 16.6 \\
\hline 1997 & 19.9 & 28.3 & 23.0 & 22.8 & 15.1 & 15.5 & 16.1 & 17.2 \\
\hline 1998 & 18.2 & 28.9 & 25.5 & 19.7 & 15.6 & 19.3 & 14.5 & 17.3 \\
\hline 1999 & 20.3 & 29.9 & 23.6 & 18.8 & 16.8 & 16.2 & 14.0 & 17.2 \\
\hline 2000 & 22.8 & 27.5 & 26.0 & 21.5 & 14.6 & 12.6 & 13.1 & 17.3 \\
\hline 2001 & 19.9 & 25.4 & 29.2 & 21.6 & 18.3 & 13.7 & 12.5 & 17.5 \\
\hline 2002 & 19.8 & 31.0 & 25.9 & 20.1 & 19.2 & 16.0 & 10.8 & 17.7 \\
\hline 2003 & 15.9 & 24.4 & 24.5 & 20.9 & 15.6 & 13.7 & 10.3 & 15.7 \\
\hline 2004 & 15.2 & 21.3 & 30.2 & 23.5 & 15.7 & 11.2 & 12.9 & 16.4 \\
\hline 2005 & 15.5 & 22.3 & 24.1 & 18.6 & 15.6 & 12.2 & 10.8 & 14.9 \\
\hline 2006 & 13.1 & 22.9 & 25.6 & 21.5 & 16.4 & 9.2 & 7.7 & 14.9 \\
\hline 2007 & 17.1 & 22.6 & 24.6 & 22.9 & 16.7 & 14.8 & 10.3 & 16.2 \\
\hline 2008 & 14.1 & 27.8 & 26.5 & 22.1 & 15.9 & 10.7 & 13.3 & 16.2 \\
\hline 2009 & 13.9 & 20.9 & 26.4 & 19.4 & 15.7 & 7.6 & 6.4 & 14.3 \\
\hline 2010 & 13.7 & 22.3 & 24.5 & 23.1 & 14.6 & 9.2 & 9.3 & 14.8 \\
\hline 2011 & 14.6 & 27.5 & 32.9 & 23.9 & 14.5 & 8.9 & 9.2 & 16.8 \\
\hline 2012 & 11.7 & 23.1 & 26.9 & 26.2 & 16.2 & 8.3 & 9.7 & 15.6 \\
\hline 2013 & 9.7 & 20.8 & 26.3 & 24.1 & 17.9 & 9.8 & 8.3 & 14.9 \\
\hline 2014 & 9.8 & 14.8 & 24.6 & 22.6 & 13.4 & 10.1 & 6.9 & 13.0 \\
\hline 2015 & 8.0 & 16.0 & 22.5 & 18.6 & 16.5 & 9.9 & 8.1 & 12.5 \\
\hline 2016 & 10.9 & 17.9 & 22.2 & 22.3 & 15.6 & 10.4 & 7.1 & 13.5 \\
\hline 2017 & 9.9 & 15.6 & 20.6 & 21.7 & 14.4 & 8.3 & 8.6 & 12.5 \\
\hline 2018 & 15.1 & 19.1 & 23.7 & 23.1 & 16.2 & 10.3 & 6.0 & 14.4 \\
\hline
\end{tabular}

The numbers in bold indicate the relevant age maxima.

https://www.scotpho.org.uk/health-wellbeing-and-disease/suicide/data/scottish-trends. 
TA B LE 3 Life satisfaction in Scotland, 2008-2018 (mean = 7.686)

\begin{tabular}{|c|c|c|c|c|}
\hline Age $25-34$ & $-0.0573(1.73)$ & $-0.3236(8.96)$ & $-0.3357(8.81)$ & $-0.3351(8.34)$ \\
\hline Age $35-44$ & $-0.2334(7.34)$ & $-0.5052(13.74)$ & $-0.5463(14.10)$ & $-0.5187(12.68)$ \\
\hline Age 45-54 & $-0.3830(12.31)$ & $-0.5495(14.73)$ & $-0.6065(15.36)$ & $-0.5720(13.70)$ \\
\hline Age $55-64$ & $-0.2295(7.35)$ & $-0.3171(8.08)$ & $-0.3981(9.55)$ & $-0.3432(7.78)$ \\
\hline Age $65-74$ & $0.1653(5.18)$ & $-0.1360(2.91)$ & $-0.1970(3.93)$ & $-0.1222(2.32)$ \\
\hline Age 75+ & $-0.0219(0.65)$ & $-0.1541(2.97)$ & $-0.1832(3.26)$ & $-0.0409(0.69)$ \\
\hline Borders & $0.1926(3.95)$ & $0.0384(0.85)$ & $0.0929(1.94)$ & $0.1013(2.02)$ \\
\hline Dumfries and Galloway & $0.2021(4.01)$ & $0.0965(2.06)$ & $0.1221(2.48)$ & $0.1208(2.34)$ \\
\hline Fife & $0.0854(2.38)$ & $0.0149(0.45)$ & $0.0222(0.65)$ & $0.0357(0.98)$ \\
\hline Forth Valley & $0.1094(2.44)$ & $0.0534(1.29)$ & $0.0471(1.07)$ & $0.0441(0.94)$ \\
\hline Grampian & $0.2666(7.72)$ & 0.1211 (3.78) & $0.0584(1.72)$ & $0.0655(1.85)$ \\
\hline Glasgow and Clyde & $-0.2124(6.55)$ & $-0.1533(5.10)$ & $-0.1333(4.22)$ & $-0.1114(3.34)$ \\
\hline Highland & $0.3072(6.95)$ & $0.1810(4.42)$ & $0.1555(3.59)$ & $0.2001(4.36)$ \\
\hline Lanarkshire & $-0.0318(0.85)$ & $-0.0321(0.92)$ & $-0.0413(1.12)$ & $-0.0347(0.89)$ \\
\hline Lothian & $0.0343(0.99)$ & $-0.0690(2.15)$ & $-0.0815(2.43)$ & $-0.0756(2.15)$ \\
\hline Orkney & $0.3051(5.85)$ & $0.1098(2.27)$ & $0.0850(1.70)$ & $0.0861(1.65)$ \\
\hline Shetland & $0.3683(6.94)$ & $0.2141(4.36)$ & $0.2135(4.15)$ & $0.2490(4.53)$ \\
\hline Tayside & $0.1478(3.65)$ & $0.0717(1.92)$ & $0.0726(1.85)$ & $0.0850(2.08)$ \\
\hline Western Isles & $0.4113(8.35)$ & $0.3255(7.13)$ & $0.3431(7.00)$ & $0.3668(7.04)$ \\
\hline$<1$ portion fruit and veg & & $0.1333(3.26)$ & $0.1386(3.15)$ & $0.1129(2.43)$ \\
\hline 1 but $<2$ fruit and veg & & $0.1996(6.89)$ & $0.1807(5.84)$ & $0.1619(4.96)$ \\
\hline 2 but $<3$ fruit and veg & & $0.2750(9.48)$ & $0.2537(8.19)$ & $0.2301(7.04)$ \\
\hline 3 but $<4$ fruit and veg & & 0.3548 (11.97) & $0.3098(9.78)$ & $0.2749(8.23)$ \\
\hline 4 but $<5$ fruit and veg & & 0.3996 (12.78) & $0.3489(10.45)$ & $0.3025(8.62)$ \\
\hline 5 but $<6$ fruit and veg & & $0.4514(13.31)$ & $0.3853(10.63)$ & 0.3404 (8.92) \\
\hline 6 but $<7$ fruit and veg & & 0.4726 (12.37) & 0.4209 (10.34) & $0.3678(8.59)$ \\
\hline 7 but $<8$ fruit and veg & & 0.4745 (10.47) & $0.4102(8.53)$ & $0.3581(7.13)$ \\
\hline $8+$ fruit and veg & & 0.4547 (11.04) & $0.3960(9.11)$ & $0.3489(7.62)$ \\
\hline Male & & $-0.0013(0.10)$ & $-0.0194(1.26)$ & $-0.0240(1.49)$ \\
\hline Log equivalized income & & & $0.2557(22.69)$ & $0.2531(21.06)$ \\
\hline BMI & & & & $-0.0086(5.78)$ \\
\hline Year dummies & Yes & Yes & Yes & Yes \\
\hline Education dummies & No & Yes & Yes & Yes \\
\hline Marital status & No & Yes & Yes & Yes \\
\hline Labour force status & No & Yes & Yes & Yes \\
\hline Constant & 7.6623 & 8.2716 & 5.7618 & 6.0067 \\
\hline Adjusted $R^{2}$ & 0.0211 & 0.1639 & 0.1767 & 0.1748 \\
\hline N & 60,772 & 60,565 & 51,314 & 44,373 \\
\hline
\end{tabular}

Source: Scottish Health Survey, 2008-2018. Excluded categories age 16-24; zero portions of fruit and vegetables; Ayrshire and Arran. 


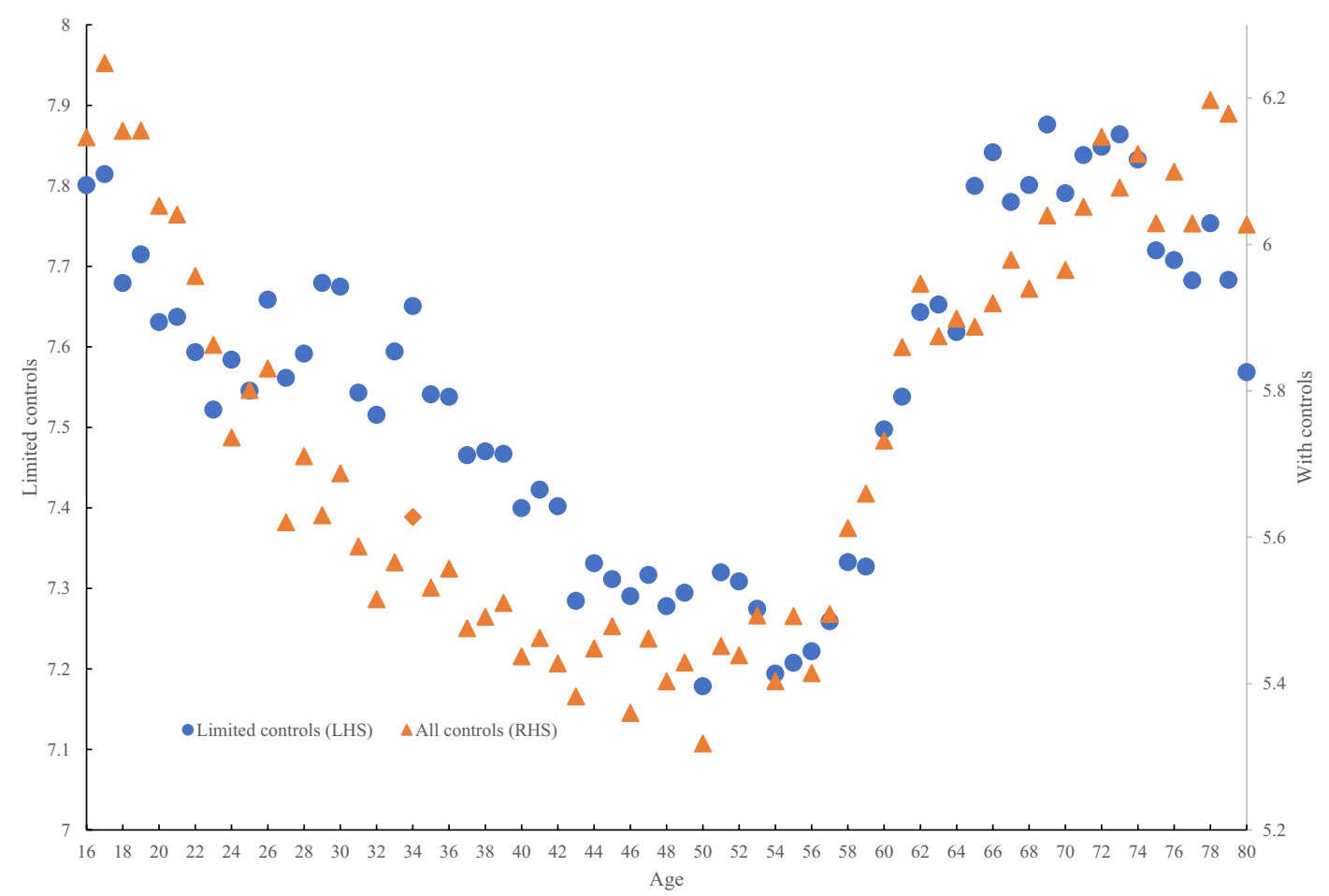

FIG URE 1 Life satisfaction in Scotland, Scottish Health Survey, 2008-2018 [Colour figure can be viewed at wileyonlinelibrary.com]

observed in anxiety coincides with a subsequent increase observed in each of the life satisfaction, happiness and worthwhile measures.

As shown in Table 2, suicides in Scotland also peak in midlife for both men and women. Overall, for the first selected six years ${ }^{3}$ the peak rates are in the $45-54$ category while the peak is in 35-44 in the most recent data. For males, peaks are mostly in the 35-44 category and those for females are mainly in the 45-54 category.

Earlier papers have provided many estimates of midlife nadir in the UK in happiness and a zenith in unhappiness data. They generally have midpoint lows in the late forties. Blanchflower and Oswald (2009) reported a U-shape for the UK in Eurobarometer life satisfaction data from 1976 to 2002. Blanchflower (2020a) found evidence in UK sub-samples of U-shapes in a number of surveys including the Annual Population Surveys (APS) of 2016-2018 as well as the Eurobarometers; the European Social Surveys; the European Quality of Life Surveys; the World Values Survey; and the International Social Survey Programme. Blanchflower and Graham (2020) found a U-shape for the UK in data from the Gallup World Poll while Blanchflower and Graham (2021) found a U-shape in APS data for 2016-2018. In a previous paper, Bell and Blanchflower (2007) found using Eurobarometer data for 1973-2003 that there was a U-shape in four-step life satisfaction for the UK with a minimum at age 44 with controls for five Scottish areas (table 14 column 4).

There has also been some work for the UK using longitudinal data from the British Household panel study (Cheng et al., 2017) who found that "this article provides what appears to be the first longitudinal (fixed effects)

${ }^{3}$ All of the years 1982-2018 separately by gender are available at https://www.scotpho.org.uk/health-wellbeing-and-disease/suicide/data/scott ish-trends 
TAB LE 4 Life satisfaction Scotland, 2008-2018 (mean = 7.686)

\begin{tabular}{|c|c|c|c|}
\hline & & Least educated & Most educated \\
\hline Age 25-34 & $-0.3507(9.29)$ & $-0.1968(2.55)$ & $-0.3156(7.10)$ \\
\hline Age $35-44$ & $-0.6415(16.82)$ & $-0.5757(7.78)$ & $-0.5586(12.04)$ \\
\hline Age 45-54 & $-0.7472(19.33)$ & $-0.6890(9.40)$ & $-0.6380(13.19)$ \\
\hline Age 55-64 & $-0.5110(12.58)$ & $-0.3776(5.06)$ & $-0.4861(9.15)$ \\
\hline Age 65-74 & $0.0537(1.23)$ & $0.2583(3.35)$ & $-0.0924(1.52)$ \\
\hline Age $75+$ & $0.1950(4.07)$ & $0.3996(4.94)$ & $0.0339(0.46)$ \\
\hline Borders & $0.0679(1.40)$ & $0.1226(1.72)$ & $-0.0039(0.06)$ \\
\hline Dumfries and Galloway & 0.0967 (1.94) & $0.1071(1.50)$ & $0.0946(1.37)$ \\
\hline Fife & $-0.0095(0.27)$ & $-0.0053(0.11)$ & $-0.0076(0.16)$ \\
\hline Forth Valley & $-0.0214(0.48)$ & $0.0104(0.16)$ & $-0.0488(0.79)$ \\
\hline Grampian & $0.0241(0.70)$ & $0.0729(1.45)$ & $-0.0307(0.64)$ \\
\hline Glasgow and Clyde & $-0.1776(5.52)$ & $-0.2305(4.99)$ & $-0.1232(2.73)$ \\
\hline Highland & $0.1392(3.16)$ & $0.1796(2.75)$ & $0.0919(1.56)$ \\
\hline Lanarkshire & $-0.0737(1.97)$ & $-0.0758(1.45)$ & $-0.0561(1.05)$ \\
\hline Lothian & $-0.1277(3.76)$ & $-0.1060(2.09)$ & $-0.1462(3.16)$ \\
\hline Orkney & $0.0752(1.47)$ & $0.1816(2.36)$ & $-0.0364(0.54)$ \\
\hline Shetland & 0.1941 (3.69) & $0.2687(3.59)$ & $0.0982(1.34)$ \\
\hline Tayside & $0.0416(1.04)$ & $0.1316(2.28)$ & $-0.0585(1.06)$ \\
\hline Western Isles & $0.3310(6.61)$ & $0.3667(4.91)$ & $0.2940(4.40)$ \\
\hline$<1$ portion fruit and veg & $0.1819(4.04)$ & 0.1857 (3.09) & $0.1385(1.94)$ \\
\hline 1 but $<2$ fruit and veg & $0.1971(6.20)$ & $0.2052(4.77)$ & $0.1343(2.74)$ \\
\hline 2 but $<3$ fruit and veg & $0.2692(8.48)$ & $0.2809(6.45)$ & $0.1954(4.04)$ \\
\hline 3 but $<4$ fruit and veg & $0.3153(9.73)$ & $0.3117(6.89)$ & $0.2663(5.50)$ \\
\hline 4 but $<5$ fruit and veg & $0.3336(9.81)$ & $0.3057(6.25)$ & $0.2974(5.99)$ \\
\hline 5 but $<6$ fruit and veg & $0.3659(9.93)$ & $0.4001(7.24)$ & $0.2868(5.53)$ \\
\hline 6 but $<7$ fruit and veg & $0.4152(10.04)$ & $0.4629(7.16)$ & $0.3279(5.84)$ \\
\hline 7 but $<8$ fruit and veg & $0.3847(7.88)$ & $0.4051(5.18)$ & $0.3206(5.02)$ \\
\hline $8+$ fruit and veg & $0.3982(9.05)$ & $0.3806(5.08)$ & $0.3367(5.89)$ \\
\hline Male & $-0.0213(1.37)$ & $-0.0067(0.29)$ & $-0.0479(2.33)$ \\
\hline Log equivalized income & $0.3157(28.63)$ & $0.3385(19.84)$ & $0.3120(20.93)$ \\
\hline Smoker Ever & $-0.1823(11.46)$ & $-0.1835(7.41)$ & $-0.1586(7.78)$ \\
\hline Own house outright & $0.0842(3.78)$ & $0.0271(0.80)$ & $0.1772(5.91)$ \\
\hline Part rent/mortgage & $-0.0906(1.18)$ & $-0.0840(0.77)$ & $-0.1336(1.21)$ \\
\hline Rent & $-0.3118(14.34)$ & $-0.3269(9.62)$ & $-0.2868(10.10)$ \\
\hline Rent free & $-0.0422(0.63)$ & $-0.2073(2.11)$ & $0.1139(1.25)$ \\
\hline High blood pressure & $-0.1687(9.26)$ & $-0.1842(7.29)$ & $-0.1291(4.89)$ \\
\hline Angina & $-0.1971(4.99)$ & $-0.1523(3.20)$ & $-0.4069(4.84)$ \\
\hline Heart attack & $-0.2117(4.71)$ & $-0.2158(3.97)$ & $-0.1981(2.15)$ \\
\hline Heart murmur & $-0.0555(1.43)$ & $-0.1150(2.06)$ & $0.0320(0.59)$ \\
\hline
\end{tabular}


TABLE 4 (Continued)

\begin{tabular}{|c|c|c|c|}
\hline & & Least educated & Most educated \\
\hline Abnormal heart rhythm & $-0.3071(10.47)$ & $-0.3287(8.06)$ & $-0.2614(6.16)$ \\
\hline Other heart trouble & $-0.1628(3.48)$ & $-0.1458(2.33)$ & $-0.1762(2.42)$ \\
\hline Stroke & $-0.4868(10.87)$ & $-0.4789(8.75)$ & $-0.5022(5.70)$ \\
\hline Diabetes & $-0.1731(5.49)$ & $-0.1910(4.68)$ & $-0.1158(2.21)$ \\
\hline COPD & $-0.6329(16.72)$ & $-0.6074(13.13)$ & $-0.7022(9.25)$ \\
\hline Walk 5 min last 4 weeks & $-0.6596(25.06)$ & $-0.7348(21.46)$ & $-0.4953(11.40)$ \\
\hline Cannot walk & $-1.5905(20.48)$ & $-1.6837(17.66)$ & $-1.3515(8.96)$ \\
\hline Constant & 5.2847 & 4.9322 & 5.3108 \\
\hline Adjusted $R^{2}$ & 0.1699 & 0.1841 & 0.1355 \\
\hline$N$ & 49,895 & 26,404 & 22,758 \\
\hline
\end{tabular}

Note: Excluded: Ayrshire and Arran; paying mortgage; can walk. Columns 2 and 3 exclude those still in education. Least educated includes those with ALS 16 or less and most educated includes those age 17 and over. Angina to diabetes refer to "ever" experienced. All equations include year, education, marital status, and labour force dummies.

Source: Scottish Health Survey.

multi-country evidence for a human nadir or midlife 'crisis'". These results have been confirmed by Clark (2019) using 14 sweeps of the British Household Panel Study where he distinguishes between two potential explanations of this shape: a pure lifecycle or aging effect, and a fixed cohort effect depending on year of birth. Panel analysis controlling for fixed effects continues to produce a $\mathrm{U}$-shaped relationship between well-being and age, although the U-shape he finds is flatter for life satisfaction than for the GHQ measure of mental well-being. He concludes "the results show that, even controlling for individual fixed effects, both life satisfaction and GHQ scores remain U-shaped in age." Movshuk (2011) also used the BHPS and found that there was a U-shape even when controlling for cohort effects. Longitudinal data, which is subject to attrition bias, especially by the less happy, and crosssectional evidence in the UK are all consistent with a U-shape.

Blanchflower and Oswald (2009) also found an inverted U-shape in depression using data from the Labour Force Surveys of 2004Q2-2007Q1. Blanchflower (2020a) subsequently used the same data for 2014-2018 and found an inverted U-shape and also with these same LFS data for mental illness, phobias, and panics. The Annual Population Survey data for the UK on anxiety were also examined for 2016-2018 and also showed a hump shape.

The only other study we know of that examined whether there were U-shapes in well-being in Scotland was Blanchflower et al. (2012) produced them using the Scottish Health Surveys of 2008/9 with a minimum in life satisfaction in the age range 45-54. They also found a maximum using the GHQ36 score in the same age range. We now move to look at well-being in Scotland and find consistent evidence with these earlier findings with the same variables a decade and a Great Recession later.

\section{4 | EMPIRICAL EVIDENCE ON MIDLIFE PEAK IN WELL-BEING IN SCOTLAND AND ENGLAND, 2008-2019}

Data on 11-step life satisfaction from the Scottish Health Survey ${ }^{4}$ is used in Table 3 for the years 2008-2018, with just under 61,000 observations on the full sample. The Scottish Health Survey (SHES) has been carried out annually since 2008 and prior to this was carried out in 1995, 1998, and 2003. The 2018 survey was the fourteenth in

${ }^{4}$ https://www.gov.scot/publications/scottish-health-survey-2018-volume-1-main-report/ 
TABLE 5 Life satisfaction in the UK by country, 2016-2019

\begin{tabular}{|c|c|c|c|c|}
\hline & England & Scotland & Wales & $\begin{array}{l}\text { Northern } \\
\text { Ireland }\end{array}$ \\
\hline Age 25-34 & $-0.3304(19.30)$ & $-0.4173(9.85)$ & $-0.4143(8.45)$ & $-0.4575(5.36)$ \\
\hline Age 35-44 & $-0.6072(34.93)$ & $-0.7366(17.41)$ & $-0.6379(12.84)$ & $-0.6884(7.97)$ \\
\hline Age $45-54$ & $-0.7463(42.84)$ & $-0.8837(21.04)$ & $-0.7769(15.77)$ & $-0.9348(0.72)$ \\
\hline Age 55-64 & $-0.5243(29.68)$ & $-0.5437(12.83)$ & $-0.4805(9.66)$ & $-0.6383(7.22)$ \\
\hline Age $65-74$ & $0.0467(2.42)$ & $0.0834(1.81)$ & $0.0879(1.64)$ & $-0.0860(0.89)$ \\
\hline Age 75+ & $-0.0136(0.57)$ & 0.1161 (2.09) & 0.1246 (1.98) & $0.0238(0.20)$ \\
\hline Male & $-0.1067(16.58)$ & $-0.1261(8.40)$ & $-0.1077(6.24)$ & $-0.1819(5.71)$ \\
\hline Constant & 8.0926 & 8.2015 & 8.1287 & 8.9125 \\
\hline Adjusted $R^{2}$ & 0.0705 & 0.0889 & 0.0715 & 0.0880 \\
\hline$N$ & 302,965 & 54,981 & 45,448 & 12,010 \\
\hline Minimum & 48 & 46 & 45 & 48 \\
\hline
\end{tabular}

Notes:: excluded category ages 16-24. All equations include year (3), education (7), marital (5), and labour force status (5) dummies. Minimum obtained by replacing the age bands with a quadratic in age differentiating with respect to zero and solving.

Source: Annual Population Survey, January 2016-December 2019

the series. Commissioned by the Scottish Government Health Directorates, the series provides regular information on aspects of the public's health and factors related to health which cannot be obtained from other sources.

The first well-being question we examined is virtually identical to Q1 above.

Q5. "How satisfied are you with life nowadays, where zero is extremely dissatisfied and 10 is extremely satisfied?"

Even in the raw data from the SHES, there is a $U$-shape in life satisfaction. The average life satisfaction scores were as follows, with a minimum in the age $45-54$ grouping-16-24 = 7.81; $25-34=7.74 ; 35-44=7.57$; $45-$ $54=7.43 ; 55-64=7.59 ; 65-74=7.99$ and 75+=7.81, with an overall mean of 7.69 .

In Table 3, we estimate an OLS equation and include seven age bands with the youngest group of 18-24 excluded. ${ }^{5}$ Column 1 , in addition, includes year and region dummies. Column 2 adds portions of fruit and vegetables eaten the day before and full sets of education, marital, and labour force status dummies and gender. Column 3 adds the log of equivalized income which lowers the sample size by just under 10,000, while column 4 adds BMI which reduces it even further to 44,373 . It is clear that more fruit and vegetables raises life satisfaction as found in Blanchflower et al. (2012) using 2008/9 sweeps of these data. Income raises happiness and a higher BMI lowers it. Well-being is especially low in Glasgow and Clyde and highest in Shetlands and the Western Isles. In all cases, there is an obvious $U$-shape in the age 45-54 category. If instead of using these six age dummies, we replace them with age and its square, take the two coefficients, differentiate, and solve the minimum of the U-shape works out to age 48 which is the same as found in Blanchflower (2020b).

\footnotetext{
${ }^{5} \mathrm{~A}$ reviewer suggested we look at the Ramsey reset test at baseline to determine if there are higher powers of the age variable that have been omitted. We included age and ages squared and age cubed the specification failed the reset test with these Scottish Health Survey life satisfaction data $(F=58.49)$. The results with the other variables and data files are similar. The test can reject for lots of reasons not just non-linearities in age, but because of other non-linearities and interactions. Part of the problem is that it (1) it often rejects in large samples because of small deviations from linearity (e.g. it has high power) and (2) it does not tell you what is wrong. It may well be the case that there are omitted variables, but the test does not help you find them. As a fix, we include instead a set of seven age band dummies. In addition, we replaced them with a flexible functional form using a full set of single year of age variables in the charts to pick up any additional non-linearities. This more flexible approach also confirmed the $U$-shape in age up to around age seventy, which is our main point.
} 


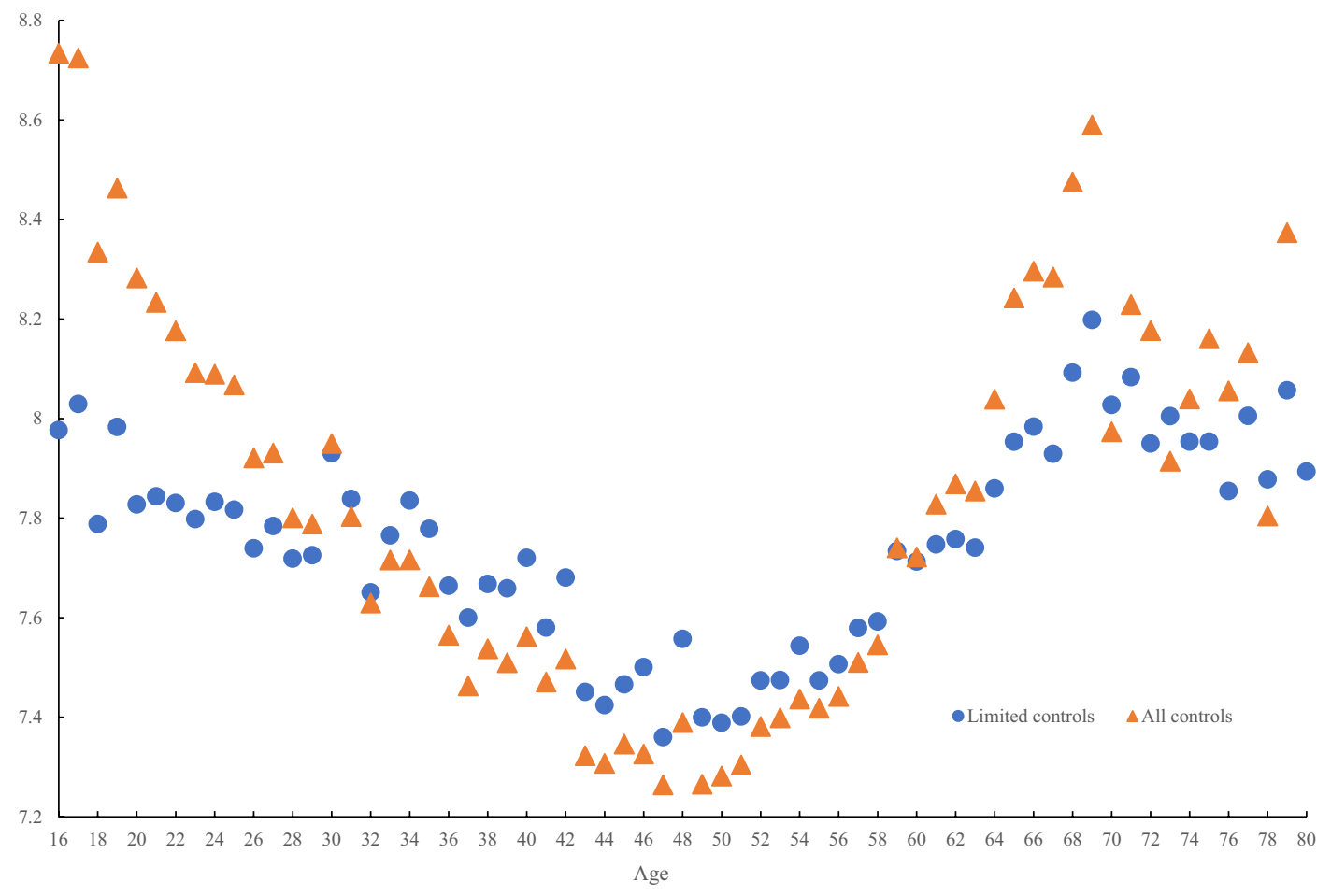

FI G U RE 2 Life satisfaction, Scotland, 2016-2019, Annual Population Surveys [Colour figure can be viewed at wileyonlinelibrary.com]

An alternative way to examine the relation between age and life satisfaction is instead to include a full set of age dummies for each single year of age. This is what is plotted in Figure 1 which simply adds the coefficients to the constant, first with only year and region controls ("limited controls" and then adding controls from column 4 for income, BMI, gender, economic and marital status, and education ("with controls"). It is clear that there are $\mathrm{U}$-shapes in both cases with minima around age 50.

The first column of Table 4 adds controls for home ownership, smoking, and exercise and includes a series of health variables identifying if the respondent has ever had high blood pressure, a stroke, etc. plus COPD, etc. The BMI variable is insignificant in the presence of these variables and it is omitted as doing so raises the sample size. The final two columns split by levels of education and in all three equations there is a clear $\mathrm{U}$-shape in age once again minimizing in the age range $45-54$.

Table 5 performs a similar exercise using data from the UK Annual Population Surveys of 2016-2019 but this time for the Q1 question on life satisfaction for each of the four home countries. The same age bands are included along with controls for gender, year, marital and labour force status, and education. Sample sizes are just under 43,000 . Once again there are U-shapes for all four countries with minima in the age band 45-54. Replacing the age dummies with quadratics and differentiating with respect to age and solving gives minima from age 45 to 48 in all cases, in the same age band of 40-49 which had the biggest negative coefficients. Figure 2 generates similar U-shapes for Scotland as in Figure 1 but this time using APS life satisfaction with minima around age 48.

In contrast, Figure 3 looks at unhappiness using the anxiety question Q4 above also for Scotland and plots out hump shapes with and without controls, again with a peak in the late forties. Hawkes (2012) based on the earliest sweep of these APS data in 2011 also confirmed a U-shape in age in the data for the UK as a whole with a nadir in the 45-49 age group. 


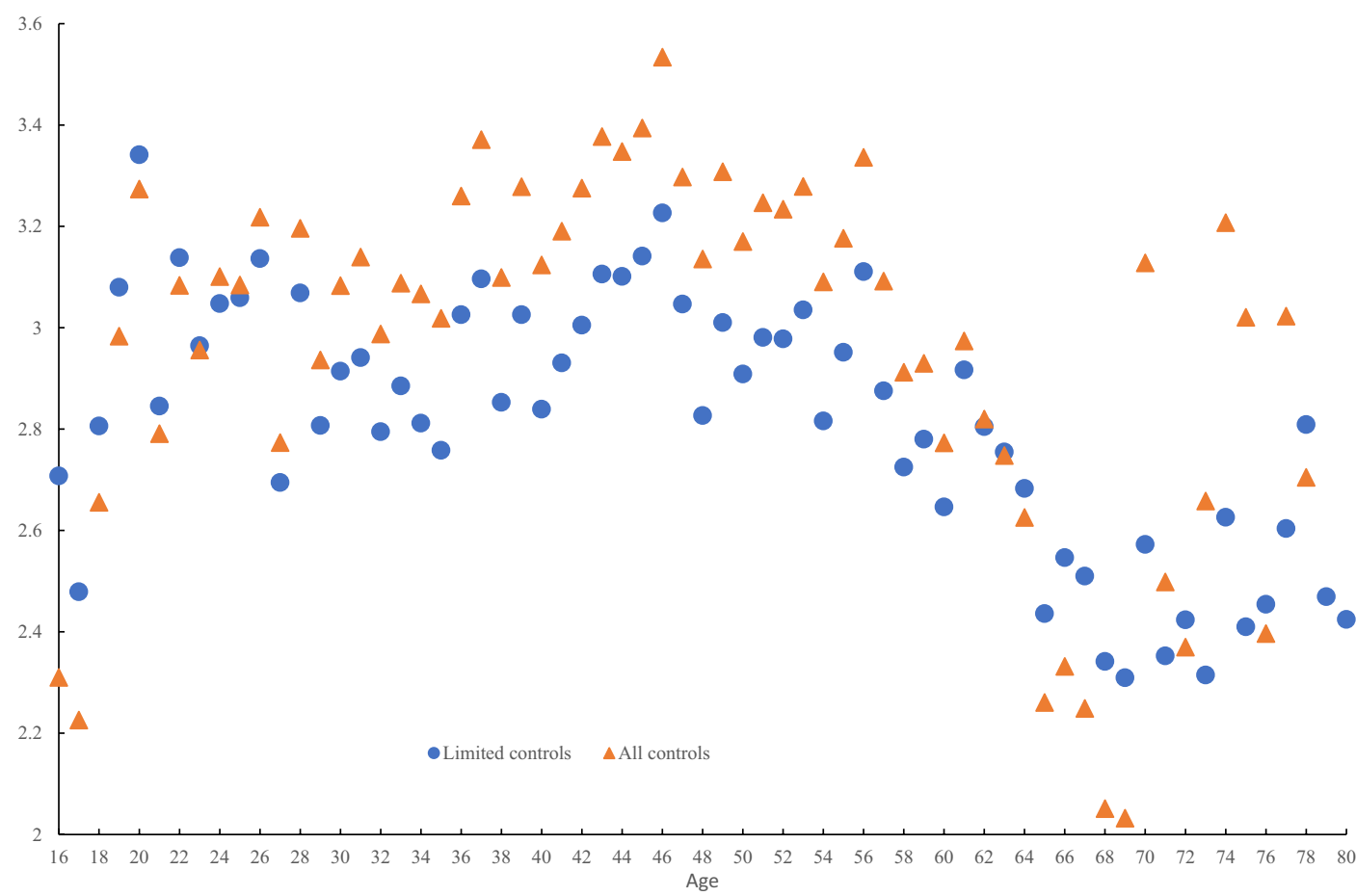

F I G U RE 3 Anxiety in Scotland, 2016-2019, Annual Population Surveys [Colour figure can be viewed at wileyonlinelibrary.com]

Table 6 uses the Health Survey for England for 2016-2017, the only years a life satisfaction question was included. As before, there are U-shapes in age. Equivalized income is only available in quintiles and happiness again rises with income. As in Scotland, more portions of fruit and vegetables are associated with higher levels of life satisfaction.

Table 7 examines a composite measure of unhappiness, the GHQ36 for Scotland, which takes the values of 0-36 and has a mean of 10.9. It is the sum of 12 questions coded from zero to three as shown below.

Q6. Been able to concentrate on whatever you're doing? Better than usual = 0; Same as usual =1; Less than usual = 2; Much less than usual $=3$.

Q7. Lost much sleep over worry? Not at all = 0; no more than usual = 1; Rather more than usual = 2; Much more than usual $=3$.

Q8. Felt you were playing a useful part in things? More so than usual =0; Same as usual = 1; Less useful than usual = 2; Much less useful $=3$.

Q9. Felt capable of making decisions about things? More so than usual =0; Same as usual = 1; Less so than usual = 2; Much less capable $=3$.

Q10. Felt constantly under strain? Not at all = 0; No more than usual = 1; Rather more than usual = 2; Much more than usual $=3$.

Q11. Felt you couldn't overcome your difficulties? Not at all = 0; No more than usual = 1; Rather more than usual = 2; Much more than usual $=3$.

Q12. Been able to enjoy your normal day-to-day activities? More so than usual = 0; Same as usual = 1; Less able than usual = 2; Much less able $=3$. 
TAB LE 6 Life satisfaction in England 2016-2017 (mean = 7.495)

\begin{tabular}{|c|c|c|c|c|}
\hline Age $25-34$ & $0.1155(1.55)$ & $-0.2838(3.29)$ & $-0.2529(2.81)$ & $-0.2784(2.79)$ \\
\hline Age $35-44$ & $0.0615(0.84)$ & $-0.4081(4.63)$ & $-0.3496(3.81)$ & $-0.4002(3.95)$ \\
\hline Age $45-54$ & $-0.1493(2.07)$ & $-0.4916(5.52)$ & $-0.4176(4.49)$ & $-0.5077(4.92)$ \\
\hline Age 55-64 & $0.0424(0.59)$ & $-0.2379(2.58)$ & $-0.1578(1.64)$ & $-0.2277(2.14)$ \\
\hline Age $65-74$ & $0.4322(5.87)$ & $-0.0561(0.51)$ & $0.0142(0.12)$ & $-0.0932(0.73)$ \\
\hline Age $75+$ & $0.1804(2.31)$ & $-0.1865(1.55)$ & $-0.0533(0.43)$ & $-0.1186(0.85)$ \\
\hline $\begin{array}{l}\text { NW and } \\
\text { Merseyside }\end{array}$ & $-0.0270(0.37)$ & $0.0683(1.01)$ & $-0.1763(2.42)$ & $0.2358(2.98)$ \\
\hline $\begin{array}{l}\text { Yorks and } \\
\text { Humberside }\end{array}$ & $-0.0878(1.10)$ & $-0.2090(2.80)$ & $-0.3329(4.18)$ & $-0.3785(4.43)$ \\
\hline West Midlands & $0.1322(1.66)$ & $-0.0073(0.10)$ & $-0.0938(1.17)$ & $-0.1760(2.03)$ \\
\hline East Midlands & $0.0199(0.25)$ & $-0.0191(0.26)$ & $-0.0886(1.10)$ & $-0.1059(1.23)$ \\
\hline Eastern & $0.1107(1.47)$ & $-0.0554(0.79)$ & $-0.1614(2.14)$ & $-0.2379(2.91)$ \\
\hline London & $0.0680(0.90)$ & $-0.1220(1.71)$ & $-0.2210(2.90)$ & $-0.2742(3.26)$ \\
\hline South East & $0.1910(2.65)$ & $0.0247(0.37)$ & $-0.0421(0.58)$ & $-0.1403(1.77)$ \\
\hline South West & $0.0302(0.38)$ & $-0.1531(2.07)$ & $-0.2013(2.54)$ & $-0.2451(2.89)$ \\
\hline $\begin{array}{l}<1 \text { portion fruit } \\
\text { and veg }\end{array}$ & & $0.1464(1.34)$ & $0.1542(1.35)$ & $0.0269(0.22)$ \\
\hline $\begin{array}{l}1 \text { but }<2 \text { fruit and } \\
\text { veg }\end{array}$ & & $0.2439(3.30)$ & $0.2358(3.06)$ & $0.1975(2.36)$ \\
\hline $\begin{array}{l}2 \text { but }<3 \text { fruit and } \\
\text { veg }\end{array}$ & & $0.3544(4.87)$ & $0.2941(3.88)$ & $0.2706(3.29)$ \\
\hline $\begin{array}{l}3 \text { but }<4 \text { fruit and } \\
\text { veg }\end{array}$ & & $0.4628(6.25)$ & $0.4297(5.59)$ & $0.3668(4.39)$ \\
\hline $\begin{array}{l}4 \text { but }<5 \text { fruit and } \\
\text { veg }\end{array}$ & & $0.4835(6.37)$ & $0.4598(5.82)$ & $0.4369(5.10)$ \\
\hline $\begin{array}{l}5 \text { but }<6 \text { fruit and } \\
\text { veg }\end{array}$ & & $0.4971(6.14)$ & $0.4674(5.56)$ & $0.4162(4.57)$ \\
\hline $\begin{array}{l}6 \text { but }<7 \text { fruit and } \\
\text { veg }\end{array}$ & & $0.4934(5.63)$ & $0.4143(4.55)$ & $0.3340(3.40)$ \\
\hline $\begin{array}{l}7 \text { but }<8 \text { fruit and } \\
\text { veg }\end{array}$ & & $0.4122(4.24)$ & $0.3512(3.48)$ & $0.2602(2.35)$ \\
\hline $8+$ fruit and veg & & $0.5831(6.72)$ & $0.5333(5.91)$ & $0.4597(4.64)$ \\
\hline Male & & $0.0498(1.49)$ & $0.0670(1.94)$ & $0.0368(0.98)$ \\
\hline BMI & & & $-0.0256(8.54)$ & $-0.0229(6.99)$ \\
\hline $\begin{array}{l}\text { Second quintile } \\
\text { income }\end{array}$ & & & & $0.1913(3.16)$ \\
\hline $\begin{array}{l}\text { Third quintile } \\
\text { income }\end{array}$ & & & & $0.3442(5.59)$ \\
\hline $\begin{array}{l}\text { Fourth quintile } \\
\text { income }\end{array}$ & & & & $0.3997(6.42)$ \\
\hline $\begin{array}{l}\text { Fifth quintile } \\
\text { income }\end{array}$ & & & & $0.4487(6.96)$ \\
\hline Year dummy & Yes & Yes & Yes & Yes \\
\hline
\end{tabular}


TABLE 6 (Continued)

\begin{tabular}{lllll}
\hline $\begin{array}{c}\text { Education } \\
\text { dummies }\end{array}$ & No & Yes & Yes & Yes \\
\hline $\begin{array}{c}\text { Marital status } \\
\begin{array}{c}\text { Labour force } \\
\text { status }\end{array}\end{array}$ & No & Yes & Yes & Yes \\
\hline Constant & 7.1377 & Yes & Yes & Yes \\
\hline Adjusted $R^{2}$ & 0.0177 & 6.9595 & 7.6586 & 0.1751 \\
\hline$N$ & 14,138 & 0.1466 & 0.1593 & 10,064 \\
\hline
\end{tabular}

Note: excluded category 0 portions fruit and vegetables, North East and ages 16-24.

Source: Health Survey of England.

Q13. Been able to face up to your problems? More so than usual $=0$; Same as usual $=1$; Less able than usual $=2$; Much less able $=3$.

Q14. Been feeling unhappy and depressed? Not at all = 0; No more than usual = 1; Rather more than usual = 2;

Much more than usual $=3$.

Q15. Been losing confidence in yourself? Not at all = 0; No more than usual = 1; Rather more than usual = 2; Much more than usual" $=3$.

Q16. Been thinking of yourself as a worthless person? Not at all = 0; No more than usual = 1; Rather more than usual $=2$; Much more than usual $=3$.

Q17. Been feeling reasonably happy, all things considered? More so than usual = 0; About same as usual = 1; Less so than usual $=2$; Much less than usual $=3$.

Table 7 shows a hump shaped relationship with unhappiness reaching a zenith in midlife as found in Blanchflower (2020c). Unhappiness is highest in Glasgow and Clyde. Figure 4 plots out the hump shape with the GHQ36 that maximizes at around age 50 also. As was done for life satisfaction, the BMI variable is dropped in the final column and additional variables are added in column 5 of Table 7 to identify poor health; home ownership, smoking, and exercise. The peak at age 45-54 is even more stark with the inclusion of these new variables.

Table 8 does the same for England. In both cases, there is a hump shape in age reaching a maximum between the ages for 45 and 54 which remains unchanged as controls are added. In both cases, higher consumption of fruit and vegetables is associated with lower unhappiness. Answers are very similar in terms of the age pattern and the consumption of fruit and vegetables if the components of GHQ36 are examined separately. The relationship between well-being and age is remarkably stable as the list of variables is altered.

Table 9 estimates separate equations for each of the 12 sub-components of the GHQ score for Scotland using the SHES. There are inverted U-shapes for nine of the 12 components based on differentiating with respect to age and solving for the minima obtained using a quadratic in age. Interestingly, sleeplessness has an inverted Ushape consistent with the findings of Blanchflower and Bryson (2020) who found that sleep duration in the USA followed a U-shape in age.

Of note is that the Great Recession had very little impact on well-being. Using four-step life satisfaction data for the Eurobarometers from the World Database of Happiness and taking the average of two estimates for each of the years from 2007, as can be seen there was little change: $2007=3.2 ; 2008=3.2 ; 2009=3.3 ; 2010=3.3$; $2011=3.3 ; 2012=3.3 ; 2013=3.3 ; 2014=3.3 ; 2015=3.3 ; 2016=3.4 ; 2017=3.4 ; 2018=3.3 ;$ and $2019=3.3$. 
TAB LE 7 GHQ36 in Scotland 2008-2018 (mean = 10.88)

\begin{tabular}{|c|c|c|c|c|c|}
\hline Age 25-34 & 0.0938 (0.99) & $0.4215(4.01)$ & $0.5434(4.87)$ & $0.5078(4.32)$ & $0.4452(4.00)$ \\
\hline Age $35-44$ & $0.4426(4.88)$ & 0.6778 (6.33) & 0.8373 (7.38) & $0.7473(6.24)$ & $0.9163(8.15)$ \\
\hline Age 45-54 & $0.8020(9.03)$ & 0.7958 (7.33) & $0.9765(8.45)$ & 0.8631 (7.07) & $1.1544(10.13)$ \\
\hline Age $55-64$ & 0.2981 (3.34) & $0.0633(0.55)$ & $0.2841(2.33)$ & 0.1654 (1.28) & 0.4237 (3.54) \\
\hline Age $65-74$ & $-0.6849(7.49)$ & $-0.2961(2.17)$ & $-0.1882(1.28)$ & $-0.2981(1.93)$ & $-0.9416(7.34)$ \\
\hline Age $75+$ & $-0.4580(4.61)$ & $-0.3074(2.01)$ & $-0.2045(1.24)$ & $-0.3715(2.13)$ & $-1.2573(8.84)$ \\
\hline Borders & $-0.3966(2.86)$ & $-0.0983(0.75)$ & $-0.1165(0.84)$ & $-0.1180(0.81)$ & $-0.1771(1.25)$ \\
\hline $\begin{array}{l}\text { Dumfries and } \\
\text { Galloway }\end{array}$ & $-0.4090(2.82)$ & $-0.1629(1.19)$ & $-0.2225(1.54)$ & $-0.2347(1.55)$ & $-0.2655(1.80)$ \\
\hline Fife & $-0.2743(2.68)$ & $-0.1118(1.16)$ & $-0.0413(0.41)$ & $-0.0578(0.55)$ & $-0.0087(0.09)$ \\
\hline Forth Valley & $-0.3812(3.00)$ & $-0.2702(2.26)$ & $-0.1579(1.24)$ & $-0.2192(1.61)$ & $-0.0272(0.21)$ \\
\hline Grampian & $-0.7535(7.71)$ & $-0.4210(4.56)$ & $-0.3398(3.45)$ & $-0.3307(3.21)$ & $-0.3265(3.23)$ \\
\hline $\begin{array}{l}\text { Glasgow and } \\
\text { Clyde }\end{array}$ & $0.1556(1.68)$ & $0.0718(0.82)$ & 0.0906 (0.99) & $0.0917(0.94)$ & $0.1898(2.01)$ \\
\hline Highland & $-0.6100(4.85)$ & $-0.3172(2.67)$ & $-0.2766(2.20)$ & $-0.2460(1.85)$ & $-0.3257(2.53)$ \\
\hline Lanarkshire & $-0.0683(0.63)$ & $-0.0654(0.65)$ & $0.0288(0.27)$ & $0.0030(0.03)$ & $0.0677(0.62)$ \\
\hline Lothian & $-0.3967(4.04)$ & $-0.1549(1.67)$ & $-0.1186(1.22)$ & $-0.1053(1.02)$ & $-0.0356(0.36)$ \\
\hline Orkney & $-0.7863(5.36)$ & $-0.3185(2.30)$ & $-0.2113(1.46)$ & $-0.1846(1.22)$ & $-0.3162(2.12)$ \\
\hline Shetland & $-0.7410(4.87)$ & $-0.3082(2.15)$ & $-0.2730(1.81)$ & $-0.3434(2.15)$ & $-0.3592(2.32)$ \\
\hline Tayside & $-0.2759(2.41)$ & $-0.0780(0.72)$ & $-0.0912(0.80)$ & $-0.0986(0.83)$ & $-0.0825(0.71)$ \\
\hline Western Isles & $-0.7794(5.50)$ & $-0.5177(3.87)$ & $-0.5472(3.80)$ & $-0.5171(3.41)$ & $-0.5884(3.98)$ \\
\hline $\begin{array}{l}<1 \text { portion } \\
\text { fruit and veg }\end{array}$ & & $-0.4566(3.79)$ & $-0.4676(3.62)$ & $-0.4208(3.09)$ & $-0.5649(4.24)$ \\
\hline $\begin{array}{l}1 \text { but }<2 \text { fruit } \\
\text { and veg }\end{array}$ & & $-0.3333(3.91)$ & $-0.2877(3.16)$ & $-0.1985(2.07)$ & $-0.3543(3.77)$ \\
\hline $\begin{array}{l}2 \text { but }<3 \text { fruit } \\
\text { and veg }\end{array}$ & & $-0.5985(7.00)$ & $-0.5775(6.33)$ & $-0.5240(5.46)$ & $-0.6577(6.99)$ \\
\hline $\begin{array}{l}3 \text { but }<4 \text { fruit } \\
\text { and veg }\end{array}$ & & $-0.7638(8.77)$ & $-0.7135(7.65)$ & $-0.6393(6.53)$ & $-0.7796(8.13)$ \\
\hline $\begin{array}{l}4 \text { but }<5 \text { fruit } \\
\text { and veg }\end{array}$ & & $-0.8327(9.07)$ & $-0.7528(7.68)$ & $-0.7023(6.82)$ & $-0.7857(7.81)$ \\
\hline $\begin{array}{l}5 \text { but }<6 \text { fruit } \\
\text { and veg }\end{array}$ & & $-0.9605(9.64)$ & $-0.8757(8.23)$ & $-0.7886(7.05)$ & $-0.9043(8.31)$ \\
\hline $\begin{array}{l}6 \text { but }<7 \text { fruit } \\
\text { and veg }\end{array}$ & & $-1.0062(9.01)$ & $-0.9323(7.82)$ & $-0.8587(6.85)$ & $-0.9948(8.17)$ \\
\hline $\begin{array}{l}7 \text { but }<8 \text { fruit } \\
\text { and veg }\end{array}$ & & $-1.0343(7.84)$ & $-0.9066(6.46)$ & $-0.9035(6.15)$ & $-0.8947(6.23)$ \\
\hline $\begin{array}{l}8+\text { fruit and } \\
\text { veg }\end{array}$ & & $-0.9830(8.18)$ & $-0.8987(7.05)$ & $-0.7537(5.61)$ & $-0.9585(7.39)$ \\
\hline Male & & $-0.9509(22.47)$ & $-0.9262(20.51)$ & $-0.9256(19.57)$ & $\begin{array}{c}-0.9131 \\
(19.87)\end{array}$ \\
\hline $\begin{array}{l}\text { Log } \\
\text { equivalized } \\
\text { income }\end{array}$ & & & $-0.3888(11.71)$ & $-0.3332(9.45)$ & $\begin{array}{c}-0.5876 \\
(17.98)\end{array}$ \\
\hline
\end{tabular}


TABLE 7 (Continued)

\begin{tabular}{|c|c|c|c|c|c|}
\hline BMI & & & & $0.0202(4$ & \\
\hline Smoker Ever & & & & & $0.3030(6.46)$ \\
\hline $\begin{array}{l}\text { Own house } \\
\text { outright }\end{array}$ & & & & & $0.0162(0.25)$ \\
\hline $\begin{array}{l}\text { Part rent/ } \\
\text { mortgage }\end{array}$ & & & & & $0.3337(1.46)$ \\
\hline Rent & & & & & $0.7380(11.52)$ \\
\hline Rent free & & & & & $0.1332(0.67)$ \\
\hline $\begin{array}{l}\text { High blood } \\
\text { pressure }\end{array}$ & & & & & $0.3857(7.17)$ \\
\hline Angina & & & & & $0.9001(7.63)$ \\
\hline Heart attack & & & & & $0.2580(1.92)$ \\
\hline Heart murmur & & & & & $0.1301(1.14)$ \\
\hline $\begin{array}{l}\text { Abnormal } \\
\text { heart rhythm }\end{array}$ & & & & & $1.1694(13.56)$ \\
\hline $\begin{array}{l}\text { Other heart } \\
\text { trouble }\end{array}$ & & & & & $0.3513(2.53)$ \\
\hline Stroke & & & & & $1.2866(9.48)$ \\
\hline Diabetes & & & & & $0.3865(4.13)$ \\
\hline COPD & & & & & $1.8482(16.42)$ \\
\hline $\begin{array}{l}\text { Walk } 5 \text { min } \\
\text { last } 4 \text { weeks }\end{array}$ & & & & & $1.5918(20.15)$ \\
\hline Cannot walk & & & & & $\begin{array}{r}-3.1697 \\
(12.87)\end{array}$ \\
\hline Year dummies & Yes & Yes & Yes & Yes & Yes \\
\hline $\begin{array}{r}\text { Education } \\
\text { dummies }\end{array}$ & No & Yes & Yes & Yes & Yes \\
\hline Marital status & No & Yes & Yes & Yes & Yes \\
\hline $\begin{array}{l}\text { Labour force } \\
\text { status }\end{array}$ & No & Yes & Yes & Yes & Yes \\
\hline Constant & 10.9545 & 11.1216 & 14.9143 & 13.7840 & 16.3923 \\
\hline Adjusted $R^{2}$ & 0.0135 & 0.1268 & 0.1303 & 0.1279 & 0.1071 \\
\hline$N$ & 55,250 & 55,174 & 47,766 & 42,190 & 46,439 \\
\hline
\end{tabular}

Source: Health Survey of Scotland.

\section{5 | WELL-BEING BY COUNTRY}

We also took the Annual Population Surveys examined above and pooled them across the UK. We then reestimated, controlling for country, both with and without controls. Results are reported in Table 10. In all eight cases, England is the least happy country. Scotland ranks second behind Northern Ireland which is the happiest of the four home countries in each of the equations.

This contrasts with our findings in an earlier paper, Bell and Blanchflower (2007) where it was found using four-step life satisfaction Eurobarometer data for 1973-2002, that Scotland had significantly lower life satisfaction than England. That is no longer the case in the raw data. Now we see that imposing the well-being weight npwt18 in England (7.68), is the same as Wales (7.68) and Scotland (7.70) but lower than Northern Ireland (7.89) with mean scores in parentheses. The rankings are similar using happiness. Even though Northern Ireland is ranked the happiest in our data, it has the highest suicide rate. Interestingly, England has the lowest rate with Scotland ranked above Wales and England. 
GHQ 36 Unhappiness - Scotland, 2008-2018, Scottish Health Survey

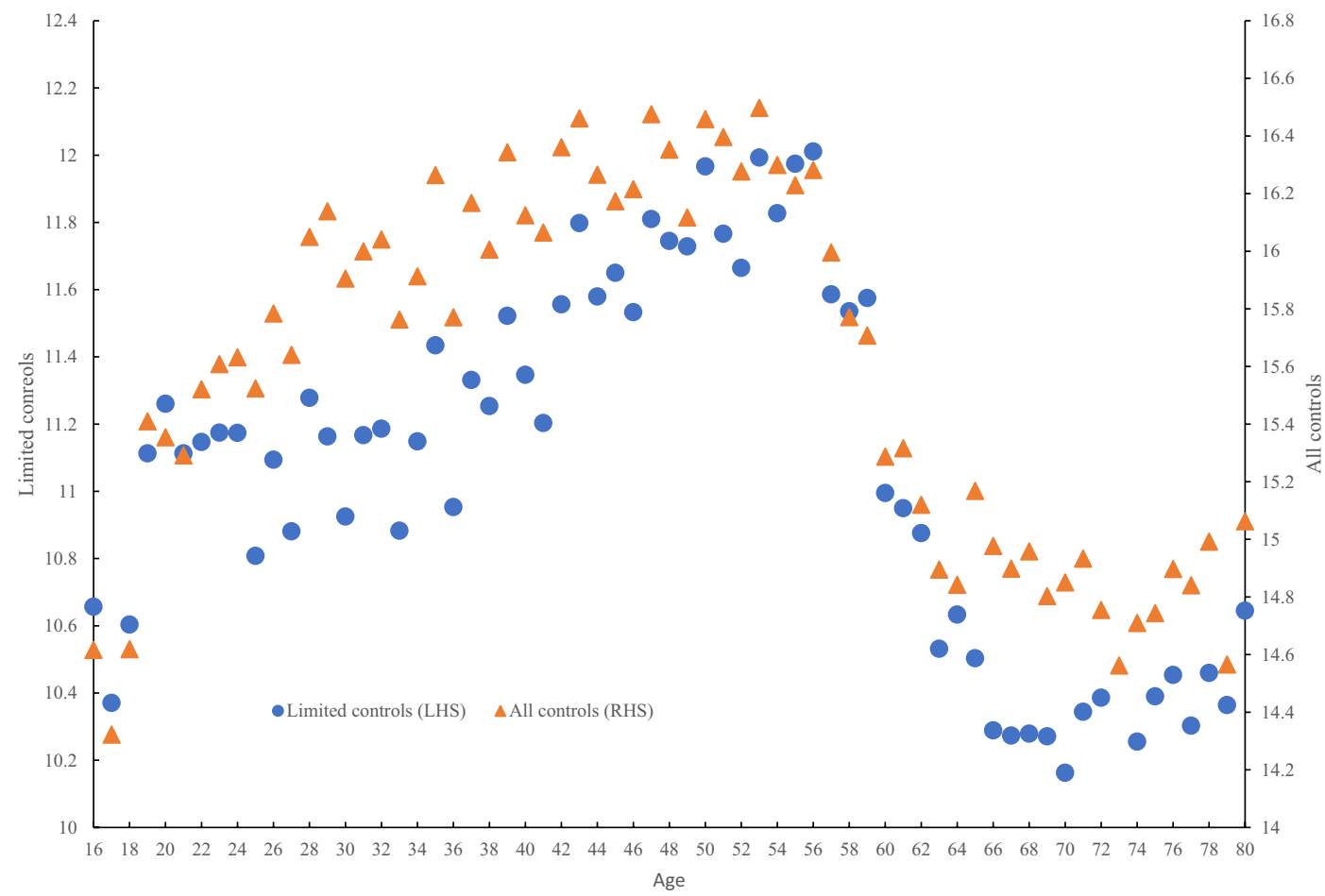

FIGURE 4 GHQ36 unhappiness-Scotland, 2008-2018, Scottish Health Survey [Colour figure can be viewed at wileyonlinelibrary.com]

Of note though is that the rankings by country based on suicide rates is rather different, as shown in Figure 5 based on data from the ONS and the Northern Ireland Statistics and Research Agency for $2018 .{ }^{6}$ It shows that suicide rates are lowest in England and highest in Northern Ireland, having taken a major jump there between 2004 and 2006. This was due to a change to the Coroners Service recording of suicides on death certificates, and therefore, figures in Northern Ireland before and after 2006 cannot be directly compared. As was clear from Table 2, suicide rates in Scotland have declined since around 2000 but are still above rates in Wales and England, and notably ticked up in 2018.

Relevant here also are the findings from the ongoing weekly UCL study of responses to the COVID-19 shutdown in the UK that there was no clear change in thoughts of death or self-harm since the easing of lockdown was announced, as shown when comparing data for England with data for Scotland and Wales in any of their 23 weekly reports from 21 March 2020 to 28 September 2020 (their figure 13). ${ }^{7}$

Table 11 reports death rates by four age groups separately by gender for each of the four home countries. In the case of Scotland, we see rises in the mortality rates of the prime age, both for men and women in the years since 2010, but not elsewhere apparently from a rise in deaths of despair, from drug poisonings. In the case of men in England, there are declines from 2001 to 2010 and then through 2016 for all four age groups. In Wales, rates are lower for three of the four age groups but have ticked up for the 35-54 age group since 2010. In Northern Ireland, 2016 rates are lower than 2001 rates, although there was a slight rise for the 15-34 group through 2010 which then fell back by 2016. In the case of Scotland, three of the four age groups were lower in both 2010 and

${ }^{6}$ Suicides in the UK, ONS, 3 September 2019. https://www.ons.gov.uk/peoplepopulationandcommunity/birthsdeathsandmarriages/deaths/datas ets/suicidesintheunitedkingdomreferencetables. https://www.nisra.gov.uk/publications/suicide-statistics 
TAB LE 8 GHQ36 in England 2003-2016 (mean = 10.694)

\begin{tabular}{|c|c|c|c|c|}
\hline Age 25-34 & $0.3766(6.66)$ & $0.7557(9.24)$ & $0.8025(8.60)$ & $0.7437(7.64)$ \\
\hline Age $35-44$ & $0.7577(13.80)$ & $1.1882(14.06)$ & $1.2538(13.05)$ & $1.1350(11.29)$ \\
\hline Age 45-54 & $1.0208(18.23)$ & $1.3889(15.77)$ & $1.4668(14.52)$ & $1.3006(12.27)$ \\
\hline Age $55-64$ & $0.6576(11.48)$ & $0.8708(9.40)$ & $0.9022(8.43)$ & $0.7868(7.01)$ \\
\hline Age 65-74 & $-0.0348(0.58)$ & $0.3390(3.02)$ & $0.4225(3.24)$ & $0.2898(2.13)$ \\
\hline Age $75+$ & $0.4371(6.90)$ & $0.6821(5.61)$ & $0.8606(5.97)$ & $0.6062(4.01)$ \\
\hline NW and Merseyside & $-0.2089(2.98)$ & $-0.1641(1.93)$ & $-0.1381(1.42)$ & $-0.0825(0.81)$ \\
\hline Yorks and Humberside & $-0.3408(4.60)$ & $-0.2078(2.30)$ & $-0.2571(2.50)$ & $-0.2908(2.71)$ \\
\hline West Midlands & $-0.3282(4.42)$ & $-0.0659(0.72)$ & $-0.0537(0.51)$ & $-0.0348(0.32)$ \\
\hline East Midlands & $-0.2455(3.31)$ & $0.0104(0.12)$ & $0.0083(0.08)$ & $0.0291(0.27)$ \\
\hline Eastern & $-0.6170(8.52)$ & $-0.2576(2.91)$ & $-0.1945(1.94)$ & $-0.1695(1.63)$ \\
\hline London & $-0.4018(5.66)$ & $-0.1165(1.33)$ & $-0.1253(1.23)$ & $-0.0500(0.47)$ \\
\hline South East & $-0.7311(10.52)$ & $-0.3825(4.49)$ & $-0.3192(3.29)$ & $-0.2823(2.80)$ \\
\hline South West & $-0.5282(7.19)$ & $-0.1821(2.04)$ & $-0.1638(1.61)$ & $-0.1534(1.45)$ \\
\hline$<1$ portion fruit and veg & & $-0.4633(3.70)$ & $-0.4941(3.42)$ & $-0.5298(3.54)$ \\
\hline 1 but $<2$ fruit and veg & & $-0.5384(6.34)$ & $-0.4697(4.83)$ & $-0.4630(4.59)$ \\
\hline 2 but $<3$ fruit and veg & & $-0.7584(9.03)$ & $-0.7234(7.51)$ & $-0.7152(7.16)$ \\
\hline 3 but $<4$ fruit and veg & & $-0.7462(8.80)$ & $-0.6716(6.92)$ & $-0.6793(6.74)$ \\
\hline 4 but $<5$ fruit and veg & & $-0.9291(10.68)$ & $-0.8458(8.49)$ & $-0.7948(7.69)$ \\
\hline 5 but $<6$ fruit and veg & & -1.0912 (11.89) & $-0.9496(9.04)$ & $-0.9277(8.51)$ \\
\hline 6 but $<7$ fruit and veg & & $-1.1132(11.11)$ & $-0.9904(8.60)$ & $-0.9718(8.13)$ \\
\hline 7 but $<8$ fruit and veg & & $-1.1143(9.84)$ & $-1.0800(8.31)$ & $-1.0500(7.79)$ \\
\hline $8+$ fruit and veg & & $-1.0571(10.33)$ & $-1.0163(8.67)$ & $-1.0259(8.40)$ \\
\hline Male & & $-0.6766(18.51)$ & $-0.6706(16.06)$ & $\begin{array}{r}-0.6861 \\
(15.86)\end{array}$ \\
\hline Log equivalized income & & & $-0.3457(11.32)$ & $\begin{array}{c}-0.3346 \\
(10.49)\end{array}$ \\
\hline BMI & & & & $0.0260(6.13)$ \\
\hline Year dummies & Yes & Yes & Yes & Yes \\
\hline Education dummies & No & Yes & Yes & Yes \\
\hline Marital status & No & Yes & Yes & Yes \\
\hline Labour force status & No & Yes & Yes & Yes \\
\hline Constant & 10.7636 & 11.2458 & 14.2343 & $13,6,043$ \\
\hline Adjusted $R^{2}$ & 0.0094 & 0.0712 & 0.0751 & 0.0751 \\
\hline$N$ & 115,589 & 71,883 & 53,575 & 48,616 \\
\hline
\end{tabular}

Note: Excludes 2007, 2011-2015. Columns 2 and 3 are 2003-2006, 2008-2010, and 2016 while column 4 drops 2016. Excluded North East, no portions age $<25$.

Source: Health Survey of England.

2016 than they were in 2001. The exception is the prime age group 35-44 that saw a decline through 2010 but then a rise subsequently. Of note in 2016 is that in all four age categories rates in 2016 were higher than in each of the other three nations. This was also true for females. Once again there are declines over time in all age groups with the exception of prime age females in Scotland that also saw a fall through 2010 but then a subsequent rise.

Schofield et al. (2016) focused on Scotland's high mortality rate and found it could not be explained simply by relative deprivation. Over time relative deprivation narrowed but relative mortality rates did not. McCartney et al. (2015) 
TAB LE 9 GHQ components and minima, Scotland, 2008-2018

\begin{tabular}{|c|c|c|c|c|}
\hline & Age & Age squared *100 & Maxima & $N$ \\
\hline GHQ36 & $0.064681(7.88)$ & $-0.07901(9.51)$ & 41 & 55,176 \\
\hline Concentrate & $0.001414(2.01)$ & $-0.00166(2.33)$ & 43 & 55,868 \\
\hline Lost sleep over worry & $0.013707(10.92)$ & $-0.01728(13.62)$ & 40 & 55,916 \\
\hline Playing a useful part in things & $\mathrm{n} / \mathrm{a}$ & & & 55,801 \\
\hline Capable of making decisions & $0.00323(4.68)$ & $-0.00236(3.38)$ & 68 & 55,917 \\
\hline Felt constantly under strain & $0.01374(11.28)$ & $-0.01742(14.15)$ & 39 & 55,911 \\
\hline Could not overcome difficulties & $0.007540(6.54)$ & -0.00941 (8.09) & 40 & 55,902 \\
\hline Able to enjoy day-to-day activities & $\mathrm{n} / \mathrm{a}$ & & & 55,915 \\
\hline Face up to problems & $0.002330(3.42)$ & $-0.00243(3.52)$ & 48 & 55,879 \\
\hline Feeling unhappy and depressed & 0.011709 (9.07) & $-0.01474(11.30)$ & 40 & 55,899 \\
\hline Losing confidence in yourself & $\mathrm{n} / \mathrm{a}$ & & & 55,898 \\
\hline $\begin{array}{l}\text { Thinking of yourself as a worthless } \\
\text { person }\end{array}$ & $0.00406(3.63)$ & $-0.00634(5.61)$ & 32 & 55,892 \\
\hline Feeling reasonably (un)happy & $0.00545(6.50)$ & $-0.00594(7.01)$ & 46 & 55,900 \\
\hline
\end{tabular}

Source: Scottish Health Survey. Controls include gender, year, region; education, marital, and labour force status controls. $T$-statistics in parentheses.

TAB LE 10 Well-being in the UK by country, 2016-2019

\begin{tabular}{|c|c|c|c|c|}
\hline & Life satisfaction & Happiness & Worthwhile & Anxious \\
\hline \multicolumn{5}{|l|}{ (a) Without controls } \\
\hline Wales & $0.0381(4.24)$ & 0.0167 (1.57) & $0.0479(5.51)$ & $-0.0042(0.29)$ \\
\hline Scotland & 0.0629 (7.59) & $0.0263(2.68)$ & $0.0181(2.27)$ & $-0.0794(5.97)$ \\
\hline Northern Ireland & $0.1881(11.30)$ & $0.1644(8.34)$ & 0.1651 (10.29) & $-0.0895(3.35)$ \\
\hline Constant & 7.6551 & 7.5160 & 7.8740 & 2.9078 \\
\hline Adjusted $R^{2}$ & 0.0005 & 0.0002 & 0.0004 & 0.0002 \\
\hline$N$ & 415,316 & 415,000 & 414,087 & 414,799 \\
\hline \multicolumn{5}{|l|}{ (b) With controls } \\
\hline Wales & $0.0416(4.29)$ & $0.0077(0.65)$ & 0.0467 (4.98) & $-0.0017(0.11)$ \\
\hline Scotland & $0.0574(6.43)$ & $0.0152(1.40)$ & 0.0274 (3.17) & $-0.0719(4.81)$ \\
\hline Northern Ireland & $0.2305(13.26)$ & $0.2174(10.25)$ & $0.2166(12.85)$ & $-0.1699(5.83)$ \\
\hline Constant & 10.1944 & 9.4174 & 9.5546 & 1.5709 \\
\hline Adjusted $R^{2}$ & 0.0824 & 0.0393 & 0.0603 & 0.0217 \\
\hline$N$ & 333,148 & 333,097 & 332,500 & 332,945 \\
\hline Mean of dep variable & & & & \\
\hline
\end{tabular}

Note: Without controls includes year dummies with controls adds controls for a quadratic in age, gender, marital and labour force status, and education. Excluded category England.

Source: Annual Population Survey, January 2016-December 2019.

examined excess mortality in Scotland and puzzled over the reason it is so high compared with England and Wales between 1995 and 2003 finding that only a quarter of the difference could be explained by underlying risk factors.

Walsh et al. (2016) note that the poor outcomes in Scotland and especially Glasgow in terms of excess mortality were caused by a series of historical factors and political decisions including historical overcrowding, deprivation 


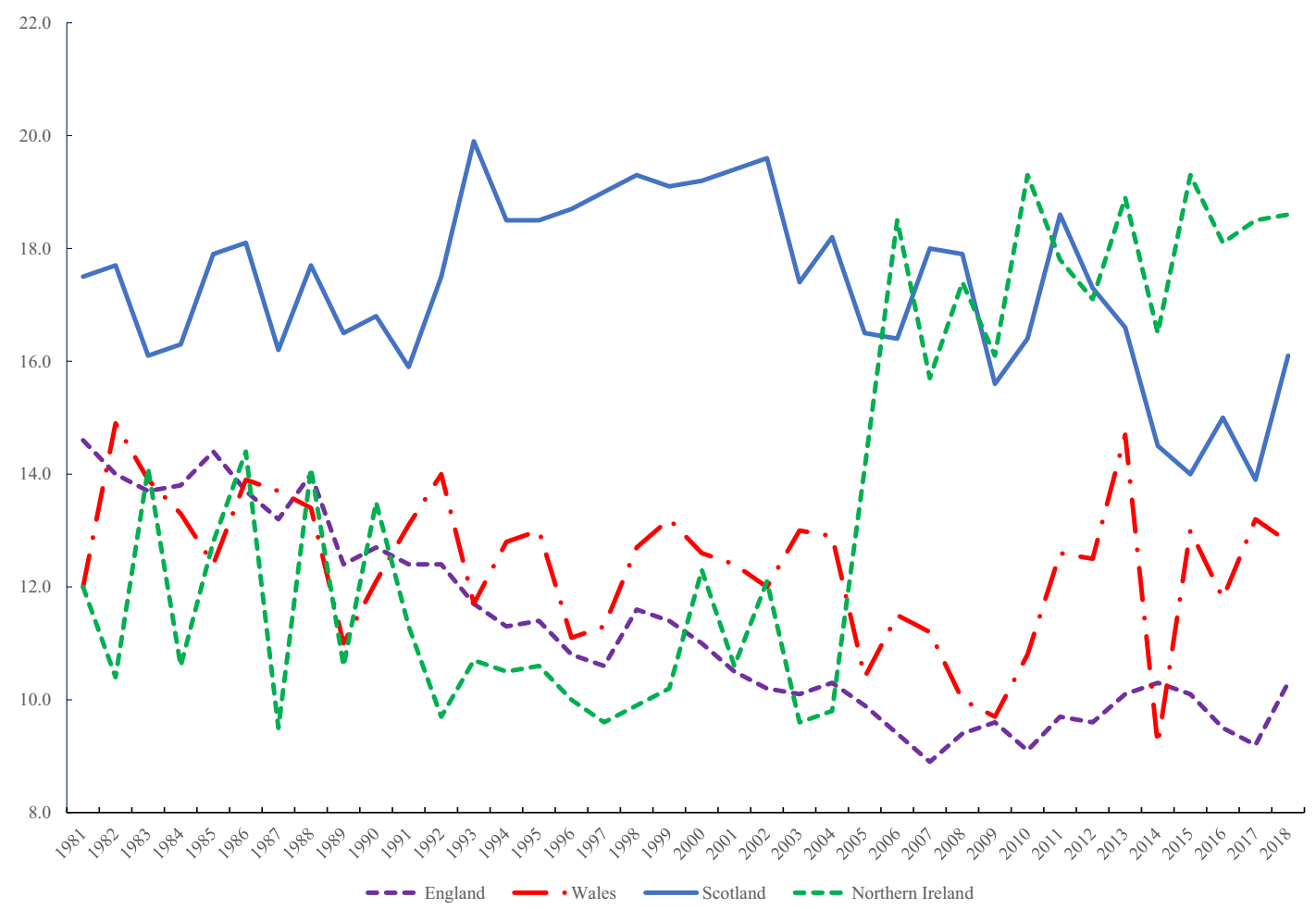

FIGURE 5 Suicide rates, by country/100,000 [Colour figure can be viewed at wileyonlinelibrary.com]

and poverty. After adjustment for differences in deprivation, the authors of the report found that premature mortality (<65 years) in Scotland was 20\% higher than in England and Wales (10\% higher for deaths at all ages); similarly, the excess for Glasgow compared with Liverpool, Manchester and Belfast they note was approximately $30 \%$ for premature mortality, and around $15 \%$ for deaths at all ages.

Interestingly, our findings from Tables 3, 4, and 7 suggest that the lowest levels of well-being across Scottish health boards are in Glasgow and Clyde. Although mortality rates are relatively high, and well-being relatively low in Glasgow and Clyde, Scotland as a whole has both relatively high mortality and high well-being compared with the rest of Great Britain. The weighted average of mortality rates in Glasgow and Clyde along with the rest of Scotland gives an overall mortality rate for Scotland that is higher than those of the other UK nations. In contrast, the weighted average of life satisfaction scores in Glasgow and Clyde and the rest of Scotland gives an overall well-being higher than that of other UK nations with the exception of Northern Ireland. Scotland scores higher on both mortality rates and wellbeing, though in both cases, levels are lower in Glasgow abd Clyde compared with the rest of Scotland.

\section{6 | DISCUSSION}

Contrary to what we found in an earlier paper, those living in Scotland are happier than those living in England despite paradoxically having higher mortality and suicide rates. It should be said though that within Scotland the lowest levels of well-being. Scotland has a nadir in well-being in midlife similar to that of England Wales and Northern Ireland. We found this using data on life satisfaction and unhappiness, where there was the mirror image of a hump shape. This finding is consistent with a series of other studies that have found well-defined U-shapes in well-being and hump shapes in unhappiness for the UK and the majority of other countries in the world. It matters not at all whether socioeconomic controls are included or not. We also get essentially the same result whether we use the Scottish Health 
TAB LE 11 Standardized age specific death rates by age, sex, and country, 2001-2016

\begin{tabular}{|c|c|c|c|c|c|}
\hline & & $15-34$ & $35-54$ & $55-74$ & $75-89$ \\
\hline \multicolumn{6}{|l|}{ Males } \\
\hline \multirow[t]{3}{*}{ England } & 2001 & 20.4 & 76.9 & 422.6 & 725.0 \\
\hline & 2010 & 14.6 & 66.2 & 316.9 & 564.2 \\
\hline & 2016 & 13.6 & 63.1 & 287.5 & 520.5 \\
\hline \multirow[t]{3}{*}{ Wales } & 2001 & 24.4 & 80.6 & 455.7 & 754.5 \\
\hline & 2010 & 20.5 & 71.9 & 336.5 & 593.8 \\
\hline & 2016 & 17.1 & 80.7 & 324.0 & 549.8 \\
\hline \multirow[t]{3}{*}{ Scotland } & 2001 & 30.1 & 107.8 & 545.9 & 788.7 \\
\hline & 2010 & 25.0 & 91.9 & 399.2 & 640.2 \\
\hline & 2016 & 21.6 & 98.4 & 365.4 & 591.7 \\
\hline \multirow[t]{3}{*}{ Northern Ireland } & 2001 & 23.3 & 81.4 & 445.5 & 772.4 \\
\hline & 2010 & 24.0 & 80.1 & 353.9 & 595.6 \\
\hline & 2016 & 20.2 & 67.0 & 308.1 & 533.0 \\
\hline \multicolumn{6}{|l|}{ Females } \\
\hline \multirow[t]{3}{*}{ England } & 2001 & 8.6 & 49.7 & 259.7 & 495.3 \\
\hline & 2010 & 6.9 & 42.7 & 203.1 & 407.2 \\
\hline & 2016 & 6.9 & 40.7 & 192.7 & 382.9 \\
\hline \multirow[t]{3}{*}{ Wales } & 2001 & 9.7 & 52.4 & 285.5 & 522.8 \\
\hline & 2010 & 9.0 & 48.2 & 221.8 & 440.3 \\
\hline & 2016 & 8.1 & 44.2 & 215.3 & 407.1 \\
\hline \multirow[t]{3}{*}{ Scotland } & 2001 & 10.8 & 61.4 & 326.9 & 554.1 \\
\hline & 2010 & 11.1 & 54.4 & 266.8 & 472.8 \\
\hline & 2016 & 9.8 & 57.3 & 243.9 & 454.5 \\
\hline \multirow[t]{3}{*}{ Northern Ireland } & 2001 & 6.9 & 51.6 & 272.0 & 511.0 \\
\hline & 2010 & 9.2 & 49.4 & 222.0 & 420.3 \\
\hline & 2016 & 9.0 & 40.8 & 216.9 & 404.8 \\
\hline
\end{tabular}

Source: Changing trends in mortality: a cross-UK comparison, 1981-2016, ONS, 7 August 2018.

Survey or the Scottish sub-sample of the Annual Population Survey. The scale of the decline in well-being from being a teenager to age 50 is substantial and around half of the fall in happiness from the Great Pandemic.

A number of psychologists have asserted, that the U-shape effect is small (Blanchflower \& Graham, 2020, 2021). Whitbourne (2009), for example, has asserted that any drops in well-being to midlife amounted to "very small if not infinitesmial (sic) blips". ${ }^{8}$ Jebb et al. (2020) argue that the fall in midlife well-being is "trivial" and go on to claim that "it is possible that the U-shaped (or other) curve exists but that it is so small that it is not practically meaningful. In other words, just because differences across age are statistically significant, that does not mean

\footnotetext{
${ }^{8}$ Opposition to a U-shape among psychologists has become increasingly desperate. In a 2014, article she was quoted as saying "despite its popularity in the popular culture, there isn't much evidence for a midlife crisis"-Anne Tergesen 'The myth of the midlife crisis,' Wall Street Journal, 12 October 2014. In another article, Whitbourne called the U-shape a "myth" and "more like a line". She claimed, "the 'dip' involves a difference between 7.2 and 7.8. No statistical analyses are provided in the paper, because, as the authors claim, the large sample size would ensure this finding would achieve statistical significance. However, if you redraw the graph, which I was able to do from the format in which I received it, the curve turns into a wobbly line in which a dip is just barely discernible." See K. Whitbourne 'That Midlife Happiness Curve? It's More Like a Line', Psychology Today, September 15th, 2018. A drop from 7.2 to 7.8 as we show is obviously large and redrawing with a bigger scale to make a dip look like a straight line is not exactly science. We show here that the $\mathrm{U}$-shape dip clearly does achieve statistical significance and is big.
} 
TAB LE 12 Life satisfaction by country, 2011-2020

\begin{tabular}{|c|c|c|c|c|}
\hline & England & Wales & Scotland & N. Ireland \\
\hline April 2011-March 2012 & 7.41 & 7.40 & 7.51 & 7.53 \\
\hline April 2012-March 2013 & 7.44 & 7.44 & 7.53 & 7.70 \\
\hline April 2013-March 2014 & 7.50 & 7.52 & 7.58 & 7.73 \\
\hline April 2014-March 2015 & 7.60 & 7.56 & 7.66 & 7.89 \\
\hline April 2015-March 2016 & 7.64 & 7.63 & 7.68 & 7.85 \\
\hline April 2016-March 2017 & 7.67 & 7.65 & 7.68 & 7.88 \\
\hline April 2017-March 2018 & 7.68 & 7.69 & 7.71 & 7.92 \\
\hline April 2018-March 2019 & 7.71 & 7.68 & 7.69 & 7.89 \\
\hline April 2019-March 2020 & 7.66 & 7.66 & 7.68 & 7.86 \\
\hline 20 March to 30 March 2020 & 7.17 & 7.29 & 7.00 & \\
\hline 27 March to 6 April 2020 & 7.06 & 6.90 & 7.22 & \\
\hline 3 April to 12 April 2020 & 6.93 & 6.91 & 6.70 & \\
\hline 9 April to 19 April 2020 & 7.05 & 7.20 & 7.02 & \\
\hline 17 April to 26 April 2020 & 6.73 & 6.63 & 7.05 & \\
\hline 24 April to 3 May 2020 & 6.94 & 6.46 & 7.21 & \\
\hline 30 April to 10 May 2020 & 7.19 & 7.10 & 6.85 & \\
\hline 7 May to 17 May 2020 & 6.93 & 7.20 & 6.89 & \\
\hline 14 May to 17 May 2020 & 6.99 & 6.34 & 6.66 & \\
\hline 21 May to 24 May 2020 & 6.98 & 6.76 & 6.83 & \\
\hline 28 May to 31 May 2020 & 7.28 & 6.82 & 6.89 & \\
\hline 4 June to 7 June 2020 & 7.13 & 6.96 & 7.20 & \\
\hline 11 June to 14 June 2020 & 6.88 & 6.91 & 6.47 & \\
\hline 18 June to 21 June 2020 & 6.92 & 7.04 & 6.34 & \\
\hline 25 June to 28 June 2020 & 7.01 & 6.69 & 7.60 & \\
\hline 2 July to 5 July 2020 & 6.92 & 7.21 & 6.97 & \\
\hline 8 July to 12 July 2020 & 7.07 & 7.04 & 6.78 & \\
\hline 15 July to 19 July 2020 & 6.89 & 6.82 & 7.27 & \\
\hline 22 July to 26 July 2020 & 7.00 & 7.02 & 7.13 & \\
\hline
\end{tabular}

Source: ONS. There are no weekly data for Northern Ireland.

that these differences have practical significance. Researchers in past studies have generally not taken effect size into account, ... At some point, an effect size becomes so small that it is truly trivial and lacks practical significance. For our Cantril ladder scale, respondents reported (and probably thought) in terms of the nearest whole scale point from 1 to 10 . Therefore, it seemed that differences below 1.00 should be considered quite small."

Interestingly, Jebb et al. (2020) did not cite any non-trivial life event with a change in well-being as large as 1 life satisfaction point. If we look at the decline in life satisfaction in the "with controls" line in Figure 1 , it is from 8.0 at 16 to 7.1 at age 50 or 0.9 life satisfaction points and is 1.4 life satisfaction points in Figure 2 "with controls". The drop is less in the raw data of 0.6 points without controls+in the two figures. Average life satisfaction for married individuals is 8.0, versus 7.49 for widowed so the drop to the midlife nadir of losing a spouse in Scotland.

Table 12 reports annual data on life satisfaction from the ONS for the four home countries using the Annual Population Survey. It also reports data conducted weekly from March 2020 through the end of July 2020 for 
England, Wales, and Scotland. It shows a dramatic fall in life satisfaction especially in Scotland where it reached a low of 6.34 in mid-June. It has picked up since then, and in the most recent data sits at 7.13, although it should be said that the data are noisy. The drop from 7.68 to 7.13 is about the same as the drop of 0.6 points in the raw data described above. Clearly not trivial.

Work at University College London has also found there were big drops in life satisfaction using Q1 above although they do not report separate country estimates. Their survey started in mid-March 2020 and found a much sharper drop to around 5.5. Since that time, life satisfaction has risen steadily suggesting that adaptation is taking place. ${ }^{9}$ Life satisfaction reached 6.5 by mid-September but fell back to 6.3 in the most recent week at the end of the month.

The drops in well-being from youth to midlife are clearly not trivial in Scotland. They are comparable to major life events such as losing a spouse or becoming unemployed. They are also of comparable magnitude to the collapse in well-being experienced during the Great Pandemic.

The evidence of a $\mathrm{U}$-shape in well-being for Scotland in the recent period is compelling. It is confirmed by a similar peak in suicide rates. Mortality rates of the prime age in Scotland have risen more than elsewhere in the UK in large part because of a rise in drug poisoning deaths.

There is a Scottish happiness curve in age with a nadir in midlife at around age 48. The decline in well-being from youth to midlife in Scotland is clearly neither trivial nor an infinitesimal blip. It is huge, consequential and important. Those in prime age in Scotland, based on our data, are likely to be especially vulnerable to the COVID-19 lockdown and the accompanying rise in unemployment which has caused dramatic rises in depression, anxiety, and despair in the spring and autumn of 2020.

\section{ORCID}

David G. Blanchflower iD https://orcid.org/0000-0002-2856-7039

\section{REFERENCES}

Argyle, M. (1999). Causes and correlates of happiness. In D. Kahneman, E. Diener, \& N. Schwarz (Eds.), Wellbeing: The foundations of hedonic psychology. Russell Sage.

Argyle, M. (2001). The psychology of happiness (2nd ed.). Routledge.

Bell, D. N., \& Blanchflower, D. G. (2007). The Scots may be brave, but they are neither healthy nor happy. Scottish Journal of Political Economy, 54(2), 166-194. https://doi.org/10.1111/j.1467-9485.2007.00410.x

Blanchflower, D. G. (2020a). Unhappiness and age. Journal of Economic Behavior and Organization, 176, 461-488. https:// doi.org/10.1016/j.jebo.2020.04.022

Blanchflower, D. G. (2020b). Experienced life cycle satisfaction in Europe: A comment. Review of Behavioral Economics, 7(2), 197-200. https://doi.org/10.1561/105.000001120

Blanchflower, D. G. (2021). Is happiness U-shaped? Age and subjective well-being in 145 countries. Journal of Population Economics, 34, 575-624. https://doi.org/10.1007/s00148-020-00797-z

Blanchflower, D. G., \& Bryson, A. (2020). Unemployment disrupts sleep. NBER WP \#27814.

Blanchflower, D. G., \& Graham, C. L. (2020). The mid-life dip in well-being: economists (who find it) versus psychologists (who don't)! NBER Working Paper \#26888, March.

Blanchflower, D. G., \& Graham, C. L. (2021). The U-shape of happiness: A response. Perspectives in Psychological Science. (in press).

Blanchflower, D. G., \& Oswald, A. J. (2008). Is well-being U-shaped over the life cycle? Social Science and Medicine, 66, 1733-1749. https://doi.org/10.1016/j.socscimed.2008.01.030

Blanchflower, D. G., \& Oswald, A. J. (2009). The U-shape without controls: A response to Glenn. Social Science and Medicine, 69, 486-488. https://doi.org/10.1016/j.socscimed.2009.05.022

Blanchflower, D. G., \& Oswald, A. J. (2016). Antidepressants and age: A new form of evidence for U-shaped well-being through life. Journal of Economic Behavior and Organization, 127, 46-58. https://doi.org/10.1016/j.jebo.2016.04.010

\footnotetext{
${ }^{9}$ https://www.covidsocialstudy.org/results
} 
Blanchflower, D. G., \& Oswald, A. J. (2019). Do modern humans suffer a psychological low in midlife? Two approaches (with and without controls) in seven data sets'. In M. Rojas (Ed.), The economics of happiness. How the Easterlin paradox transformed our understanding of well-being and progress (pp. 439-453). Springer.

Blanchflower, D. G., \& Oswald, A. J. (2020). Trends of extreme distress in the USA, 1993-2019. American Journal of Public Health, 110, 1538-1544. https://doi.org/10.2105/AJPH.2020.305811

Blanchflower, D. G., Oswald, A. J., \& Stewart-Brown, S. (2012). Is psychological well-being linked to the consumption of fruit and vegetables? Social Indicators Research, 114, 785-801. https://doi.org/10.1007/s11205-012-0173-y

Case, A., \& Deaton, A. (2015). Rising morbidity and mortality in midlife among white non- Hispanic Americans in the 21st century. Proceedings of the National Academy of Sciences, 112(49), 15078-15083. https://doi.org/10.1073/pnas.15183 93112

Case, A., \& Deaton, A. (2020). Deaths of despair and the future of capitalism. Princeton University Press.

Cheng, T. C., Powdthavee, N., \& Oswald, A. J. (2017). Longitudinal evidence for a midlife nadir in human well-being: Results from four data sets. The Economic Journal, 127, 126-142. https://doi.org/10.1111/ecoj.12256

Clark, A. E. (2019). Born to be mild? Cohort effects don't (fully) explain why well-being is U-shaped in Age. In M. Rojas (Ed.), The economics of happiness. How the Easterlin paradox transformed our understanding of well-being and progress (pp. 387-408). Springer.

Daly, M. C., Oswald, A. J., Wilson, D. J., \& Wu, S. (2011). Dark contrasts: The paradox of high rates of suicide in happy places. Journal of Economic Behavior \& Organization, 80(3), 435-442. https://doi.org/10.1016/j.jebo.2011.04.007

de Pedraza, P., Guzi, M., \& Tijdens, K. (2020). Life dissatisfaction and anxiety in COVID-19 pandemic. GLO Discussion Paper, No. 544, May.

Diener, E., Oishi, S., \& Tay, L. (2018). Advances in subjective well-being research. Nature Human Behaviour, 2, $253-260$. https://doi.org/10.1038/s41562-018-0307-6

Diener, E., Suh, E. M., Lucas, R. E., \& Smith, H. L. (1999). Subjective well-being: Three decades of progress. Psychological Bulletin, 125(2), 302-376. https://doi.org/10.1037/0033-2909.125.2.276

Fortin, N., Helliwell, J. F., \& Wang, S. (2015). How does subjective well-being vary around the world by gender and age? In J. Helliwell, R. Layard, \& J. Sachs (Eds.), World Happiness Report, 2015 (pp. 42-75). Earth Institute.

Galambos, N. L., Krahn, H. J., Johnson, M. D., \& Lachman, M. E. (2020). The U shape of happiness across the life course: Expanding the discussion. Perspectives on Psychological Science, 15(4), 898-912. https://doi.org/10.1177/1745691620 902428

Glenn, N. (2009). Is the apparent U-shape of well-being over the life course a result of inappropriate use of control variables? A commentary on Blanchflower and Oswald (66:8, 2008, 1733-1749). Social Science and Medicine, 69(4), 481-485. https://doi.org/10.1016/j.socscimed.2009.05.038

Graham, C., \& Pinto, S. (2019). Unequal hopes and lives in the U.S.A.: Optimism, race, place, and premature mortality. Journal of Population Economics, 32(2), 665-733.

Graham, C., \& Pozuelo, J. R. (2017). Happiness, stress, and age: How the U curve varies across people and places. Journal of Population Economics, 30, 225-264. https://doi.org/10.1007/s00148-016-0611-2

Hawkes, N. (2012). Happiness is a U-shaped curve, highest in the teens and 70s, shows survey. British Medical Journal, 344, e1534. https://doi.org/10.1136/bmj.e1534

Jebb, A. T., Morrison, M., Tay, L., \& Diener, E. (2020). Subjective well-being around the world: Trends and predictors across the life span. Psychological Science, 31(3), 293-305. https://doi.org/10.1177/0956797619898826

McCartney, G., Russ, T. C., Walsh, D., Lewsey, J., Smith, M., Davey Smith, G., Stamatakis, E., \& Batty, G. D. (2015). Explaining the excess mortality in Scotland compared with England: Pooling of 18 cohort studies. Journal of Epidemiology and Community Health, 69, 20-27.

Movshuk, O. (2011). Why is life satisfaction U-shaped in age? Journal of Behavioral Economics and Finance, 4, $133-138$. https://doi.org/10.11167/jbef.4.133

Myers, D. G. (2000). The funds, friends, and faith of happy people. American Psychologist, 55(1), 56-67. https://doi. org/10.1037/0003-066X.55.1.56

ONS (2019). Measuring national well-being: Domains and measures. https://www.ons.gov.uk/peoplepopulationandc ommunity/wellbeing/datasets/measuringnationalwellbeingdomainsandmeasures. Accessed 23 October 2019.

Rauch, J. (2018). The happiness curve: Why life gets better after 50. St. Martin's Press.

Schofield, L., Walsh, D., Munoz-Arroyo, R., McCartney, G., Buchanan, D., Lawder, R., Armstrong, M., Dundas, R., \& Leyland, A. H. (2016). Dying younger in Scotland: Trends in mortality and deprivation relative to England and Wales, 1981-2011. Health \& Place, 40, 106-115. https://doi.org/10.1016/j.healthplace.2016.05.007

Shams, K., \& Kadow, A. (2018). Happiness across the life span: Evidence from urban Pakistan. FWU Journal of Social Sciences, Summer, Part-1, 12(1), 17-30.

Walsh, D. G., McCartney, C., Collins, M. T., \& Batty, G. D. (2016). History, politics and vulnerability: Explaining excess mortality in Scotland and Glasgow. Glasgow Centre for Population Health. 
Weiss, A., King, J. E., Inoue-Murayama, M., Matsuzawa, T., \& Oswald, A. J. (2012). Evidence for a midlife crisis in great apes consistent with the U-shape in human well-being. Proceedings of the National Academy of Sciences, 109(49), 19949-19952. https://doi.org/10.1073/pnas.1212592109

Whitbourne, S. K. (2009). Does life happiness follow a U-shaped curve? Psychology Today, December 29.

How to cite this article: Bell DNF, Blanchflower DG. The U-shape of happiness in Scotland. Scott J Polit Econ. 2021;68:407-433. https://doi.org/10.1111/sjpe.12283 